\title{
CHRONOMETRY OF THE FINAL ENEOLITHIC CEMETERIES AT ŚWIĘTE, JAROSŁAW DISTRICT, FROM THE PERSPECTIVE OF CULTURAL RELATIONS AMONG LESSER POLAND, PODOLIA AND THE NORTH-WESTERN BLACK SEA REGION
}

\begin{abstract}
The research on archaeological materials from sites 11, 15, and 20 at Święte produced a series of 13 radiocarbon dates for niche graves of the Corded Ware culture (CWC). The results are coherent and point to a range of 2550-2350 BC. This corresponds well with other results obtained for nearby CWC cemeteries in the Rzeszów Foothills, and is consistent with dates obtained for CWC graves in other regions in Lesser Poland: the Lesser Poland Upland, the Sokal Ridge, and the Lublin Upland. At the same time, the obtained absolute age range corresponds with a wave of influences from the North Pontic circle of steppe cultures and the Middle Dnieper culture. It can be synchronized with the beginning of the development of the classic variants of the Catacomb culture: the Ingul and Doniec variants.
\end{abstract}

ABSTRACT

Key words: absolute chronology, Final Eneolithic, Corded Ware culture, south-eastern Poland, Yamnaya culture, Catacomb culture 
The excavations of site 11 at Święte produced a vessel characteristic of Early Bronze Age cultures of the north-western Pontic area [Kośko et al. 2012; 2018]. The discovery has already been discussed in the context of relations linking Corded Ware culture (CWC) groups from Lesser Poland (Małopolska) with cultures of the steppe/forest-steppe zone [Kośko et al. 2012; Włodarczak 2014]. The full analysis of the Final Eneolithic materials from the Swięte cemeteries, including a series of radiocarbon dates, has made it possible to refine the chronology of contacts between these two cultural areas. Another important aspect is the chronological position of the finds from Święte in relation to other recently published Final Eneolithic discoveries from the Rzeszów Foothills, in particular to CWC cemeteries from sites 5 and 6 at Szczytna, Jarosław District [Hozer et al. 2017]. When we also take into account the materials from sites 24 and 27 at Mirocin, Przeworsk District [Machnik et al. 2019], site 7 at Skołoszów, Jarosław District [Rybicka et al. 2017], and site 26 at Chłopice, Jarosław District [Ligoda, Podgórska-Czopek 2011: 159; Szczepanek et al. 2018], it becomes possible to discuss local characteristics of the cluster of Final Eneolithic cemeteries in the Rzeszów Foothills, a mesoregion with intense traces of occupation from the 3rd millennium BC that have only recently been unveiled thanks to large-scale rescue excavations preceding construction of the A4 motorway.

Spectacular discoveries of artefacts revealing connections with the steppe/forest steppe areas (a round-based vessel from Święte 11 and a copper shaft-hole axe from grave 4 at Szczytna 6) suggest the validity of chronometric comparisons with cultural groups from the north-west Pontic area. An opportunity for refining chronology has come with the publication of a series of radiocarbon dates obtained for burials in barrows from the vicinity of Yampil in the middle Dnieper basin [Goslar et al. 2015]. This is currently the longest published list of results for a site from the western part of the forest-steppe and steppe zone. Moreover, it comes from a region being the north-western margin of the Yamnaya complex, not very distant from the CWC range in the Dniester basin, and partly overlapping with the area occupied by the Globular Amphora culture (GAC). 
$\mathrm{T} a \mathrm{~b} \mid \mathrm{e} 1$

Radiocarbon age determinations for Corded Ware culture graves from the cemeteries at Święte, Jarosław District

\begin{tabular}{|l|l|l|l|}
\hline Feature & Lab. no. & Age ${ }^{14}$ C BP & $\begin{array}{l}\text { Calendar age BC } \\
(\mathbf{6 8 . 2 \%})\end{array}$ \\
\hline Święte 11 & Poz-90875 & $3890 \pm 35$ & $2460-2340$ \\
\hline 876 & Poz-90877 & $4020 \pm 30$ & $2573-2490$ \\
\hline 1134 & Poz-90884 & $3925 \pm 35$ & $2473-2348$ \\
\hline 1149 A & Poz-42368 & $3710 \pm 35$ & $2190-2036$ \\
\hline $1149 A^{*}$ & Poz-90876 & $3875 \pm 35$ & $2455-2297$ \\
\hline $1290 \mathrm{D}$ & \multicolumn{5}{|l|}{} \\
\hline Święte 15 & Poz-90779 & $3935 \pm 30$ & $2480-2348$ \\
\hline 173 & Poz-90882 & $3855 \pm 35$ & $2452-2214$ \\
\hline 407 & Poz-90780 & $3890 \pm 35$ & $2460-2340$ \\
\hline 408 A & Poz-90781 & $3990 \pm 30$ & $2565-2473$ \\
\hline 409 & Poz-90874 & $3890 \pm 35$ & $2460-2340$ \\
\hline 427 & Poz-90782 & $4020 \pm 35$ & $2574-2489$ \\
\hline 431 & & & $2563-2350$ \\
\hline Święte 20 & Poz-90777 & $3950 \pm 35$ & $2563-2350$ \\
\hline $40 A$ & Poz-90778 & $3950 \pm 35$ & \\
\hline 43 & & & \\
\hline
\end{tabular}

*Kośko et al. 2012

1. ABSOLUTE CHRONOLOGY OF CEMETERIES FROM SITES 11, 15, AND 20 AT ŚWIĘTE

The series of 12 radiocarbon dates for CWC cemeteries at Święte (Table 1) was obtained within the framework of the "Final Neolithic communities in south-eastern Poland in light of archaeological research and interdisciplinary analyses" project, led by Anita Szczepanek (grant from National Science Centre, OPUS no. 2015/19/B/HS3/02149). One ${ }^{14} \mathrm{C}$ date had been obtained earlier for grave 1149A, when the round-based pot discovered in that grave was studied [Kośko et al. 2012: 73-74]. Thus, the series includes a total of 13 age determinations. Its length is limited by the availability of materials containing collagen of sufficient quality. The examinations only used bones from human burials. Except for a few artefacts made of animal bone (mainly tools), the analysed features did not yield any other type of radiocarbon datable materials. 


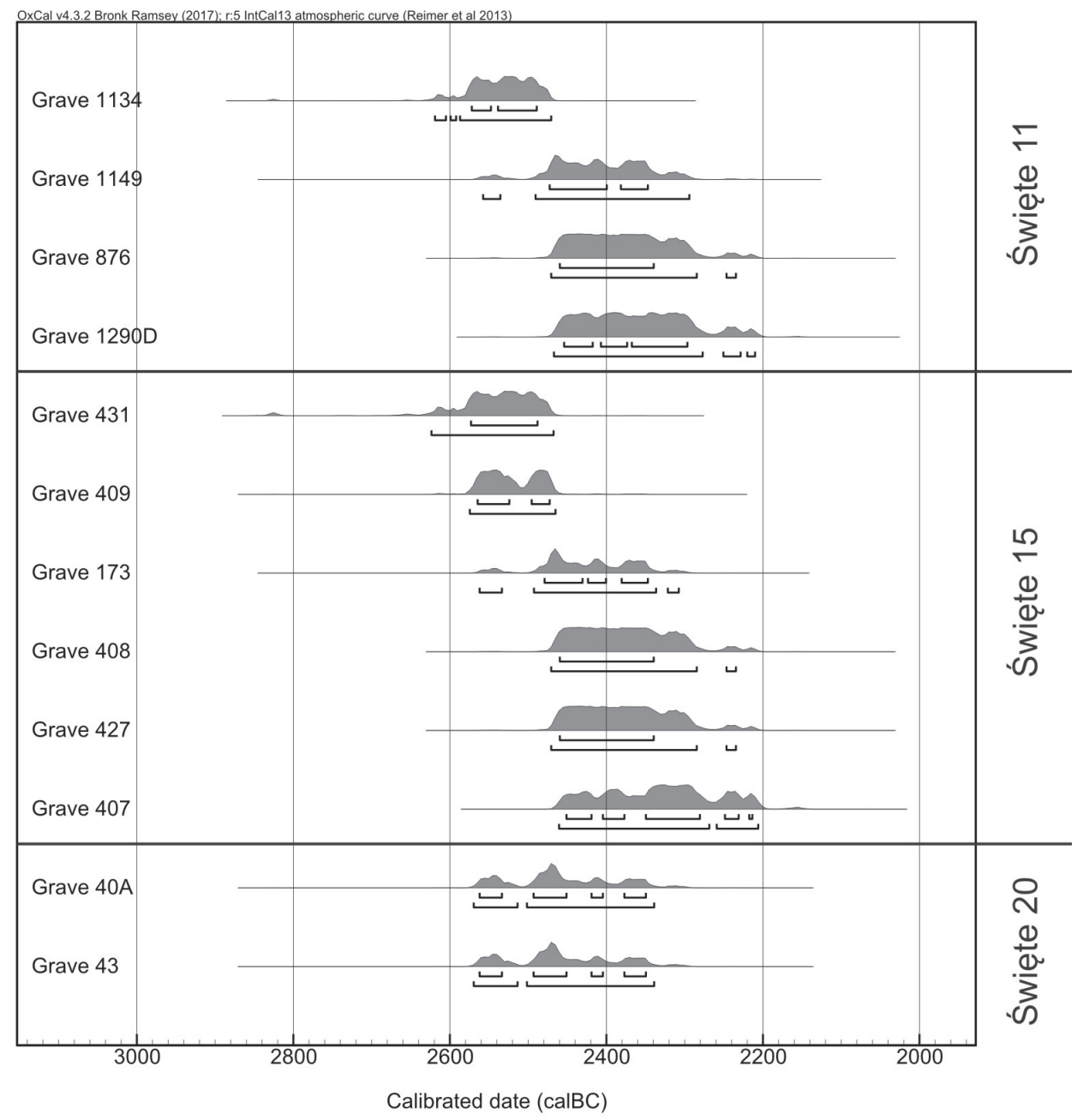

Fig. 1. Radiocarbon age determinations for CWC cemeteries at Święte, Jarosław District

${ }^{14} \mathrm{C}$ determinations were performed using the AMS technique in Poznań Radiocarbon Laboratory, directed by Professor Tomasz Goslar. Comparative analyses presented further in the text are based in the first place on date series which also come from the Poznań laboratory. Owing to their number, quality, and contexts of sample acquisition, the results produced by this laboratory are today of fundamental importance for chronological models created for the Eneolithic and the Early Bronze Age in Lesser Poland.

${ }^{14} \mathrm{C}$ dates obtained for all the three sites at Święte are similar, with the age of the samples falling, after calibration, within a generalised range of 2600-2200 BC 


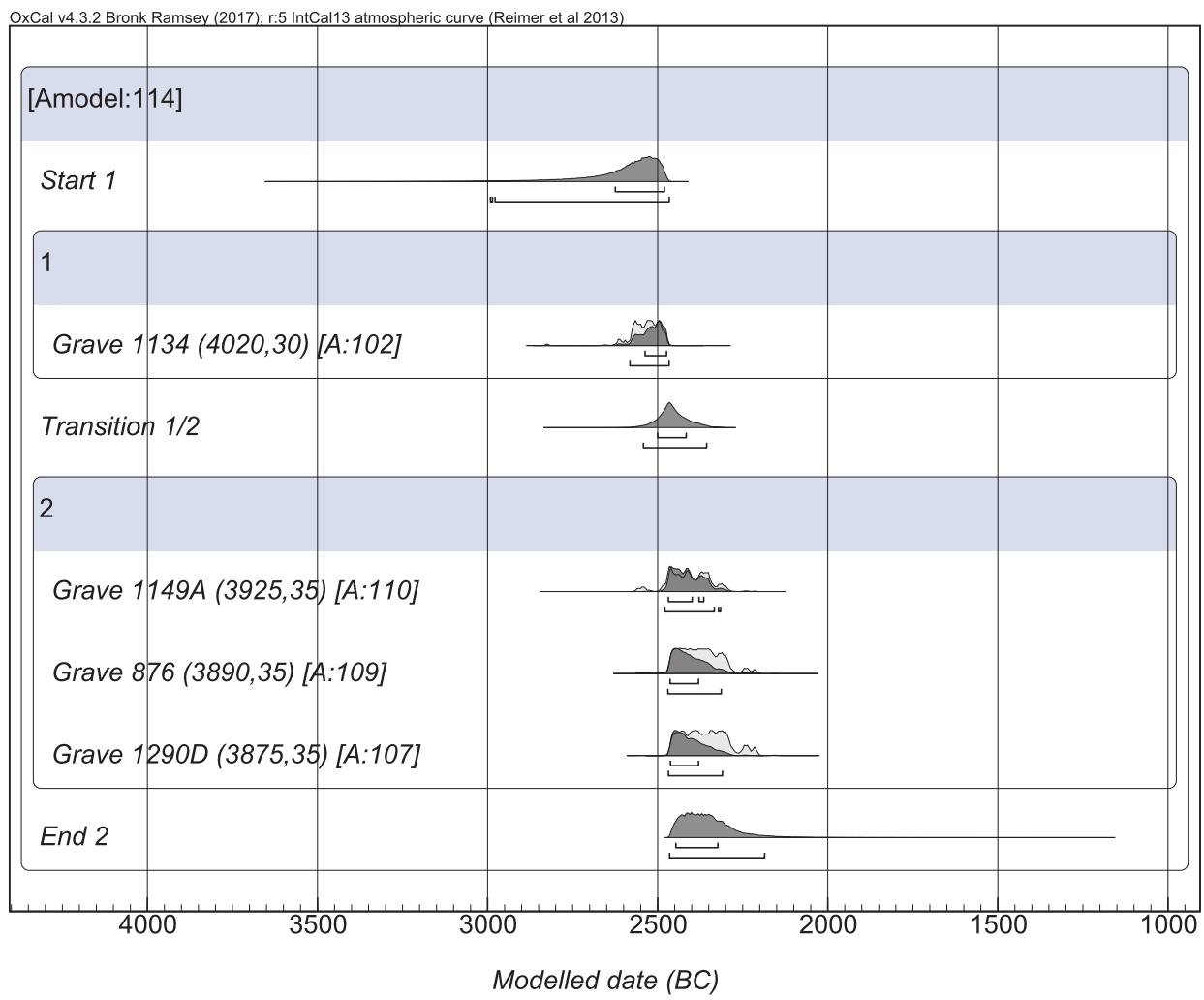

Fig. 2. Model assuming two phases of CWC cemetery at Święte, site 11

(Fig. 1), which corresponds well with dates available for graves from the younger phase of CWC in other parts of Lesser Poland [Jarosz, Włodarczak 2007; Włodarczak 2006; 2013; 2016]. These results corroborate the results of typological analyses, according to which all the materials from the Święte cemeteries fall within the "niche grave phase", chronologically corresponding with the finds of the Kraków-Sandomierz group of CWC in western Lesser Poland and the Sandomierz Upland.

Proceeding from short series of determinations and using the highest probability ranges $(1 \sigma)$, one can attempt to distinguish two phases for sites Święte 11 and 15 . The older phase would be dated to ca. $2575-2470 \mathrm{BC}$. It is represented by grave 1134 in site 11 and graves 409 and 431 in site 15 . The remaining graves link with the younger phase, dated approximately to $2480-2215$ BC. Next, assuming that all the graves from the younger stage form one coherent phase, its chronological span can be narrowed down to 2434-2323 BC for site 11 (Fig. 2) and 2454-2338 BC for site 15 (Fig. 3). The ranges (each spanning more than 100 years) calculated in this 


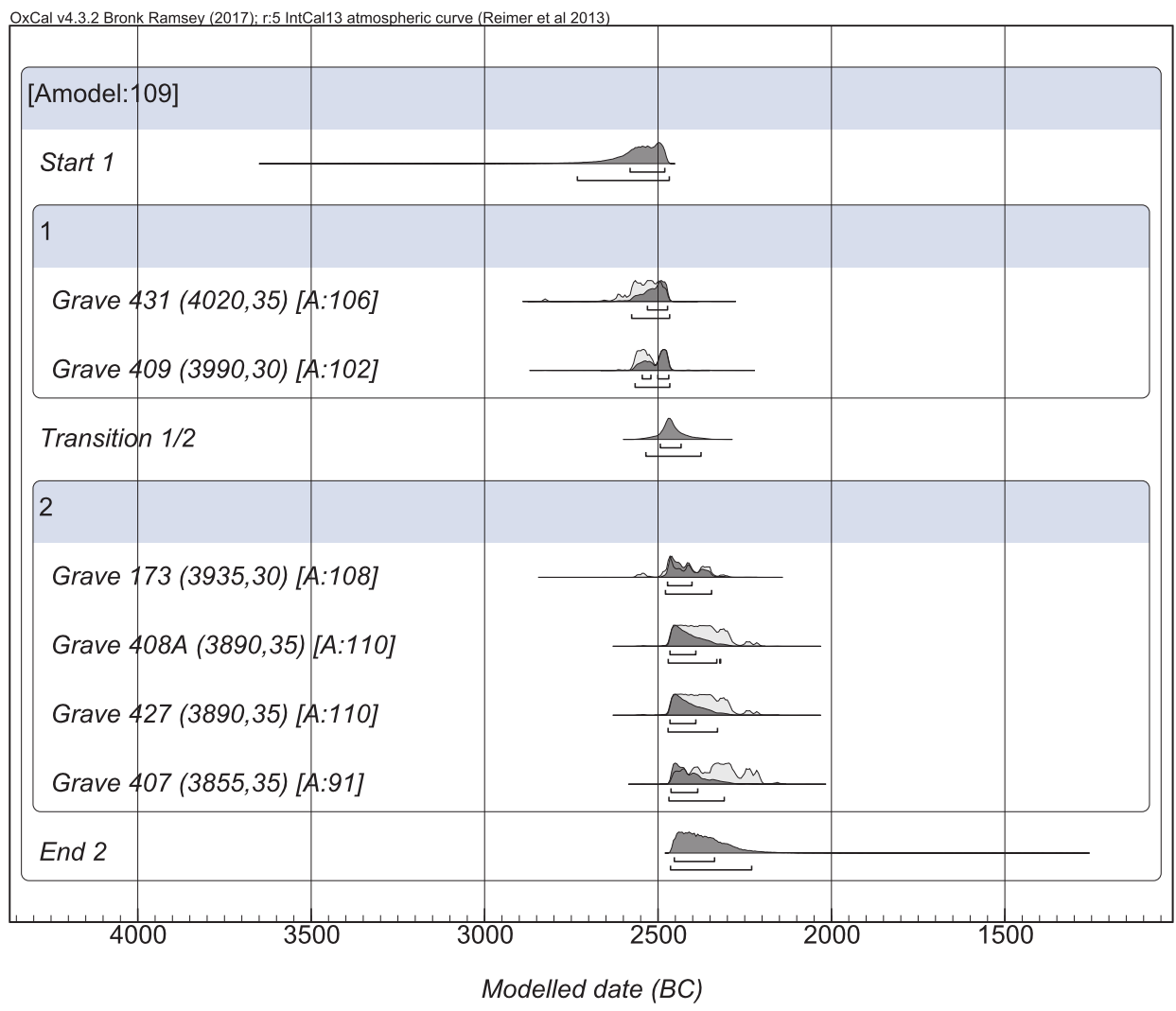

Fig. 3. Model assuming two phases of CWC cemetery at Święte, site 15

manner are quite broad due to the flattening of the calibration curve (Figs 4 and 5). Moreover, the projection of dates on the calibration curve clearly shows that the division into two phases - suggested by calibration ranges of particular determinations - can be only apparent, and the most likely interpretation is a maximum narrowing of the period of the site occupation to one short stage. Such a possibility has been positively verified by placing all the dates in one period ("Phase" function in the OxCal programme - Figs 4 and 5). The outcome is a range of 2530-2374 BC for site 11 and 2525-2382 BC for site 15 .

One radiocarbon date was earlier published for grave 1149A from Święte 11 on the occasion of analysing the round-based pot discovered in its vicinity (in feature 1149B) [Kośko et al. 2012]. This date (3710 $\pm 35 \mathrm{BP}$, which is $\left.2190-2036 \mathrm{BC}^{1}\right)$ was

\footnotetext{
${ }^{1}$ All radiocarbon dates have been calibrated with C. Bronk Ramsey's OxCal v.4.3.2 and using calibration curve INTCAL13 [Reimer et al. 2013]. The calibration results given in the text are with the probability range of $1 \sigma(68.2 \%)$.
} 


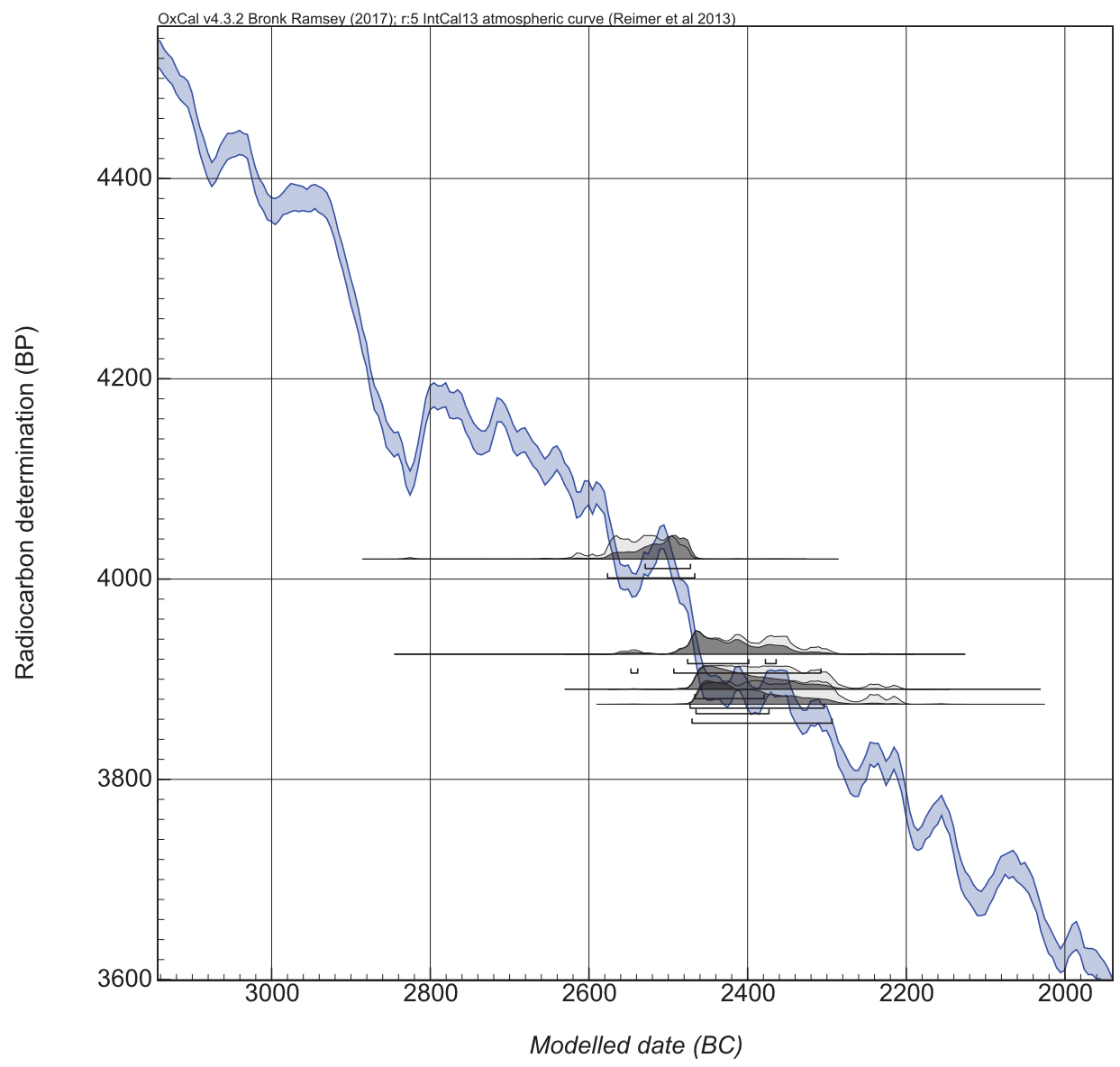

Fig. 4. Model assuming one chronological phase of CWC cemetery at Święte, site 11, plotted against calibration curve INTCAL13

surprising, as it pointed to the early phase of the Mierzanowice culture, a period previously not taken into account in the context of CWC niche graves [Górski et al. 2013; Włodarczak 2017: 380-381]. Similar dates come from Mierzanowice culture settlement features discovered in sites not far away from Święte, for example Jarosław, site 158 [Rybicka, Pelisiak 2013: 114, Table 11] and Dobkowice, site 39 [Jarosz et al. 2018: 57, Table 7]. However, the new radiocarbon date obtained for feature 1149A is earlier (2473-2348 BC) and is consistent with the chronology of other CWC graves from the Święte sites. No such late date is known thus far for a CWC grave in south-eastern Poland. The youngest result comes from a feature from Lagiewniki in the Lublin Upland (Poz-58106: 3770 \pm 35 BP) and it was obtained for a burial combining late CWC traits with elements characteristic of Early Bronze Age burial rites [Kubera, Zawiślak 2016: 356]. 


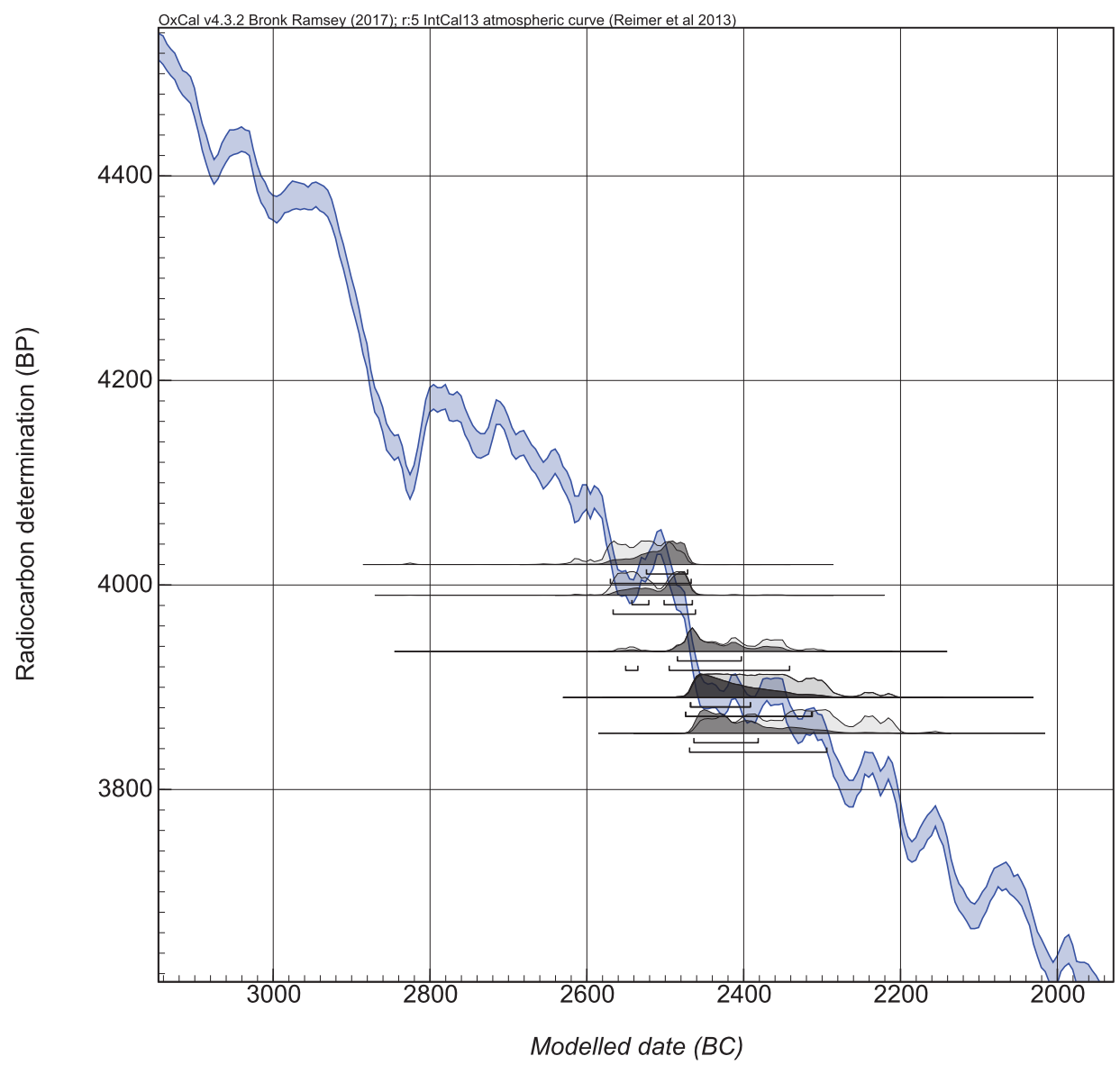

Fig. 5. Model assuming one chronological phase of CWC cemetery at Święte, site 15, plotted against calibration curve INTCAL13

It is impossible to accept both dates obtained for grave 1149A, so the earlier published determination of Poz-42368 should be considered as significantly diverging from the true age of the burial ${ }^{2}$. This is indicated by the data available for other graves, both from the site in question and throughout south-eastern Poland. The reason for such a huge discrepancy between the two dates obtained from bones retrieved from the same burial has not been established.

2 After the writing of this article, the result of the second dating of the sample Poz-42368 was obtained. The new result (Poz-109990) is $3905 \pm 30$ BP and is similar to the age of sample Poz-90884 [see Kośko et al. 2018]. 
Radiocarbon age determinations for CWC features from the Rzeszów Foothills

\begin{tabular}{|c|c|c|c|c|}
\hline Feature & Lab. no. & Age ${ }^{14} \mathrm{C}$ BP & $\begin{array}{l}\text { Calendar age } \\
\text { BC }(68.2 \%)\end{array}$ & Literature \\
\hline \multicolumn{5}{|l|}{ Chłopice 26} \\
\hline 11 & Poz-90881 & $3985 \pm 35$ & $2566-2471$ & Szczepanek et al. 2018 \\
\hline \multicolumn{5}{|c|}{ Jankowice 9 (settlement pits?) } \\
\hline 44 & MKL-1618 & $4080 \pm 90$ & $2860-2492$ & Dębiec et al. 2015 \\
\hline 146 & D-AMS00001566 & $4071 \pm 24$ & $2831-2504$ & Dębiec et al. 2015 \\
\hline \multicolumn{5}{|l|}{ Mirocin 24} \\
\hline 16 & Poz-54042 & $3815 \pm 35$ & $2333-2155$ & Machnik et al. 2019 \\
\hline 50 & Poz-90880 & $3935 \pm 35$ & $2481-2348$ & Szczepanek et al. 2018 \\
\hline $53 / 1$ & Poz-91015 & $3835 \pm 35$ & 2344-2206 & Szczepanek et al. 2018 \\
\hline 53 & Poz-54041 & $3855 \pm 25$ & $2434-2233$ & Machnik et al. 2019 \\
\hline 54 & Poz-54038 & $3940 \pm 35$ & $2546-2348$ & Machnik et al. 2019 \\
\hline 110 & Poz-90885 & $3880 \pm 35$ & $2456-2307$ & Szczepanek et al. 2018 \\
\hline \multicolumn{5}{|l|}{ Mirocin 27} \\
\hline 360 (burial 1) & Poz-54043 & $3870 \pm 35$ & $2455-2293$ & Szczepanek et al. 2018 \\
\hline 360 (burial 2) & Poz-90887 & $3860 \pm 30$ & $2454-2286$ & Szczepanek et al. 2018 \\
\hline 396 & Poz-54045 & $4010 \pm 35$ & $2570-2482$ & Machnik et al. 2019 \\
\hline \multicolumn{5}{|l|}{ Skołoszów } \\
\hline 256 & Poz-52608 & $3915 \pm 25$ & $2469-2348$ & $\begin{array}{l}\text { Rybicka et al. 2017: } \\
128, \text { Table } 2\end{array}$ \\
\hline 620 & Poz-49278 & $3895 \pm 35$ & $2461-2345$ & $\begin{array}{l}\text { Rybicka et al. 2017: } \\
128, \text { Table } 2\end{array}$ \\
\hline \multicolumn{5}{|l|}{ Szczytna 5} \\
\hline 217 & Poz-90878 & $3935 \pm 35$ & $2481-2348$ & Hozer et al. 2017 \\
\hline 220 (burial 1) & Poz-90889 & $3890 \pm 35$ & $2460-2340$ & Hozer et al. 2017 \\
\hline 220 (burial 2) & UB-28881 & $3845 \pm 37$ & $2431-2208$ & Hozer et al. 2017 \\
\hline \multicolumn{5}{|l|}{ Szczytna 6} \\
\hline 2 & MKL-1033 & $4320 \pm 90$ & $3261-2780$ & Hozer et al. 2017 \\
\hline 4 & MKL-1047 & $4050 \pm 60$ & $2834-2481$ & Hozer et al. 2017 \\
\hline 4 & UB-28880 & $3951 \pm 37$ & $2564-2350$ & Hozer et al. 2017 \\
\hline
\end{tabular}


2. CHRONOLOGICAL RELATION TO OTHER CWC CEMETERIES IN THE RZESZÓW FOOTHILLS AND IN CARPATHIAN FOOTHILLS

Short series of ${ }^{14} \mathrm{C}$ dates were also obtained for other CWC sites from the Rzeszów Foothills excavated prior to the construction of the A4 motorway. Of particular importance are the results from site 6 at Szczytna where, in grave 4, unique copper artefacts have been discovered (a shaft-hole axe and earrings of the "steppe" type). Two slightly different dates were obtained for this grave in two different laboratories (Table 2). An attempt at reconciliation of these results (R_Combine function) produces a range of 2565-2468 $\mathrm{BC}$, corresponding with the beginning of the younger CWC stage in Lesser Poland ("niche grave phase"). Dated to an analogical period are richly furnished male burials from western Lesser Poland, including from Bronocice (grave XI), Malżyce (barrow 2, grave 10), Smroków (grave 1), and Zielona (grave 3) [cf. Kruk et al. 2018: 53, Fig. 11]. Assuming that grave 4 dates to the older section of the presented range (which means still within the 26th century $\mathrm{BC}$ ), we can at the same time point towards its older chronological position in relation to the majority of the other burials in the Rzeszów Foothills, which already originate from the second half of the 3rd millennium BC.

The ${ }^{14} \mathrm{C}$ date for grave 2 from Szczytna site 6 suggests a very early age: 3261 2780 BC (obtained in the laboratory at Skała from a charcoal sample). Similar dates were obtained in the 1990s in the Kiev laboratory for bones from several CWC burials in Lesser Poland, including graves from Wierszczyca and Zielona [Machnik 1999: 233, Table 1; Włodarczak 2006: 125, Table 35]. In light of a large series of new dates (including results which verify some of the earlier determinations), these older dates should be rejected [cf. Włodarczak 2007; 2009]. In the case of grave 2 from Szczytna as well, one cannot help doubting the correctness of the mentioned date. As well, one can consider challenging its connection with the CWC complex, for example by proposing an earlier, pre-CWC origin and a connection with cultural groups from the north-west Pontic zone. Such a connection is supported by the following: (a) the position of the body (although the arrangement is disturbed, the position of the long bones suggest a burial in a supine position with the legs contracted and the knees pointing upwards, and the head pointing to the west), (b) the pit nature of the burial, and (c) the presence of a characteristic monopartite beaker, a form known from the Eneolithic, and in particular Early Bronze Age cultures of the Pontic area. In the Yamnaya culture such vessels are known primarily from the younger phase [Ivanova 2013: Figs. 3.40-3.41], although the radiocarbon date in question does not point to that period. Burials with steppe connotations, dated to the turn of the 4th and 3rd millennia BC, have recently been confirmed in a barrow site at Hubinek [unpublished material; mentioned in: Juras et al. 2018: supplementary information text]. However, the grave from Szczytna 
Radiocarbon age determinations for CWC barrows in Subcarpathian Foothills

\begin{tabular}{|c|c|c|c|c|}
\hline Feature & Lab. no. & Age ${ }^{14} \mathrm{C}$ BP & $\begin{array}{l}\text { Calendar } \\
\text { age BC } \\
(68.2 \%)\end{array}$ & Literature \\
\hline \multicolumn{5}{|c|}{ Wieliczka Foothills } \\
\hline \multicolumn{5}{|l|}{ Jawczyce } \\
\hline 1 & Poz-9454 & $4050 \pm 35$ & $2626-2491$ & Jarosz, Włodarczak 2007 \\
\hline \multicolumn{5}{|c|}{ Strzyżów Foothills } \\
\hline \multicolumn{5}{|c|}{ Bierówka, kurgan A } \\
\hline$?$ & Gd-1877 & $4240 \pm 40$ & $2907-2763$ & $\begin{array}{l}\text { Gancarski, Machnikowie } \\
1990\end{array}$ \\
\hline$?$ & Gd-3129 & $4030 \pm 100$ & $2857-2462$ & $\begin{array}{l}\text { Gancarski, Machnikowie } \\
1990\end{array}$ \\
\hline \multicolumn{5}{|c|}{ Bierówka, kurgan B } \\
\hline$?$ & Gd-2759 & $4120 \pm 80$ & $2864-2580$ & $\begin{array}{l}\text { Gancarski, Machnikowie } \\
1990\end{array}$ \\
\hline$?$ & Gd-2760 & $4070 \pm 60$ & $2850-2492$ & $\begin{array}{l}\text { Gancarski, Machnikowie } \\
1990\end{array}$ \\
\hline \multicolumn{5}{|c|}{ Krajowice, kurgan 1} \\
\hline & Gd-6009 & $3840 \pm 40$ & $2401-2206$ & $\begin{array}{l}\text { Machnik 1992; } \\
\text { Gancarski, Valde-Nowak } \\
2011\end{array}$ \\
\hline \multicolumn{5}{|l|}{ Niepla, site 14} \\
\hline & Gd-5796 & $4030 \pm 40$ & $2581-2481$ & Machnik 1992 \\
\hline \multicolumn{5}{|c|}{ Dynów Foothills } \\
\hline \multicolumn{5}{|c|}{ Średnia, site 3 , kurgan 1} \\
\hline grave & Gd-10402 & $4390 \pm 100$ & $3320-2902$ & $\begin{array}{l}\text { Machnik, Sosnowska } \\
1996\end{array}$ \\
\hline grave & Gd-10397 & $4290 \pm 90$ & $3086-2703$ & $\begin{array}{l}\text { Machnik, Sosnowska } \\
1996\end{array}$ \\
\hline \multicolumn{5}{|c|}{ Średnia, site 3, kurgan 2} \\
\hline 3 & Poz-9458 & $4015 \pm 35$ & $2573-2487$ & Jarosz, Włodarczak 2007 \\
\hline \multicolumn{5}{|c|}{ Wola Węgierska, site 3 , kurgan 1} \\
\hline grave & Gd-11353 & $3920 \pm 80$ & $2559-2291$ & $\begin{array}{l}\text { Machnik, Sosnowska } \\
1998\end{array}$ \\
\hline barrow ditch & Gd-11354 & $3860 \pm 70$ & $2459-2212$ & $\begin{array}{l}\text { Machnik, Sosnowska } \\
1998\end{array}$ \\
\hline \multicolumn{5}{|c|}{ Przemyśl Foothills } \\
\hline \multicolumn{5}{|c|}{ Przemyśl, site 81} \\
\hline & Poz-9582 & $4005 \pm 35$ & $2569-2478$ & Jarosz, Włodarczak 2007 \\
\hline
\end{tabular}




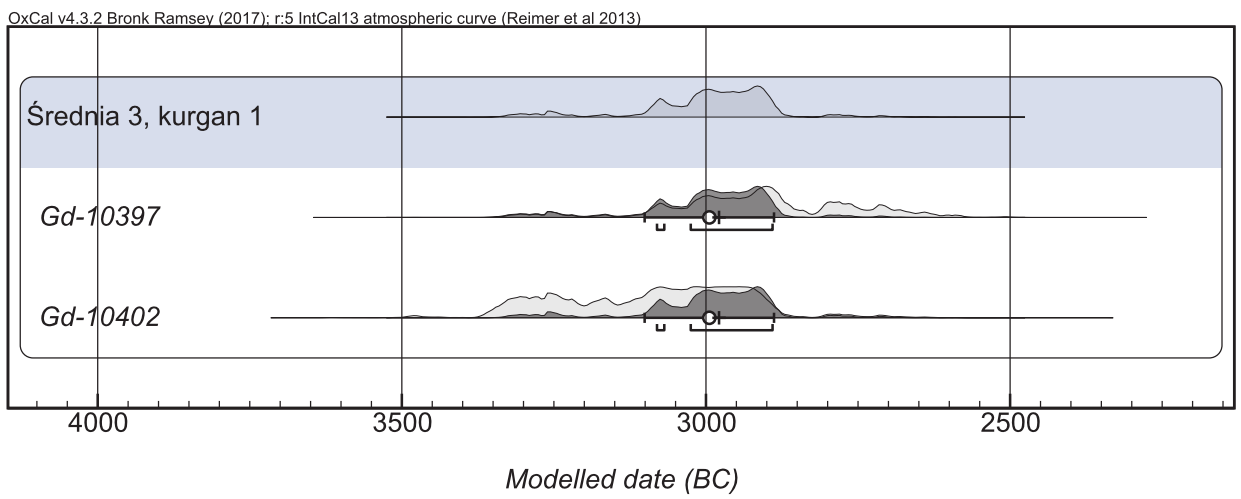

Fig. 6. Attempted age determination for central burial from barrow 1 at Średnia, site 3 (Dynów Foothills) - assuming the contemporaneity in terms of calendar age of two charcoal samples from the grave structure.

discussed here is not sufficiently distinctive and its early dating requires additional verification.

Other ${ }^{14} \mathrm{C}$ results obtained for CWC cemeteries in the Rzeszów Foothills (Chłopice, site 26, Mirocin, sites 24 and 27; Skołoszów, site 7, and Szczytna, site 5) are similar to those from the three cemeteries at Święte, and can be synchronised with them within a range of ca. 2550-2400/2350 BC. The only results pointing to a slightly older age are absolute age determinations for two settlement pits (?) from site 9 at Jankowice (Table 2) [Dębiec et al. 2015: 109]. They may correspond either to an older, "barrow" phase (its later section) or a transitional stage between the older and younger phases (ca. 2600-2500 BC). Unfortunately, the material recovered from these features is modest and undistinctive, which makes any credible attempts at refining their chronology impossible.

Comparative analyses are more difficult in the case of ${ }^{14} \mathrm{C}$ results for barrows from Carpathian foothills (Table 3). This group also includes data from sites situated relatively close to Święte, in the Dynów Foothills (Średnia and Wola Wegierska) and the Przemyśl Foothills (Przemyśl, site 81). These dates were obtained from charcoal or bone samples, and in many cases the sample context was not as good as in the previously discussed dates from the Rzeszów Foothills. The results fall within a broader timespan than the results obtained for the Święte cemeteries. First of all, there are features present which confidently date to the older stage of the Final Eneolithic (ca. 2900-2600 BC). The chronological relation between barrow graves and CWC niche graves secondarily dug into barrow mounds or occurring in flat cemeteries is a separate problem.

An assemblage of finds from barrow 1 in Średnia, site 3, linked with the oldest CWC phase in Lesser Poland, is a unique discovery [Machnik, Sosnowska 1996]. Two dates obtained from charcoal samples from the central burial construction are 


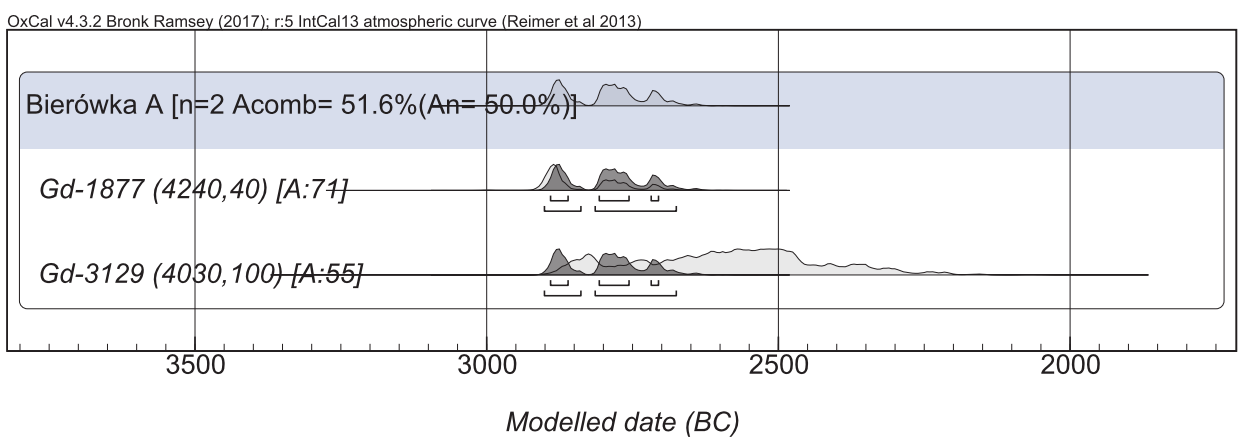

Fig. 7. Attempted reconciliation of two absolute dates (from charcoal samples) obtained for barrow A at Bierówka (Strzyżów Foothills)

divergent, but both point to the very beginning of the Final Eneolithic (the range determined using function R_Combine: 3081-2891 BC; Fig. 6). This is a surprisingly early date as compared with recent ${ }^{14} \mathrm{C}$-AMS dates for features containing artefacts from horizon A. The latter, as well as the majority of other barrow graves in Lesser Poland, commonly produce dates within a range of 2800-2600 BC (e.g. grave 1 from Gabułtów in western Lesser Poland) [Jarosz, Włodarczak 2007: 72-73]. An interesting contribution to the revision of chronology of horizon A graves was the renewed dating of the burial from Krusza Zamkowa in Kuyavia, which corrected the previous determination and set the age of the burial at the above-mentioned range of 2800-2600 BC [Goslar, Kośko 2011]. The earliest absolute age determinations for CWC barrow graves in the Polish Plain come from graves from Kruszyn [Pospieszny et al. 2015: 202, table 6] and Żygląd [Kurzyk 2011: 463-464]. They are only slightly later than the age of the Średnia barrow and can most likely be placed within ca. 2900-2800 BC. At present, there is no other individual CWC burial in a barrow known from south-eastern Poland that would be dated as early as the one from Średnia. Comparable results were obtained for features linked with this culture discovered in Ulów site in the Roztocze region [Moskal del Hoyo et al. 2017: 1401, Table 1]. However, the context of the results does not allow them to be fully confidently linked with CWC. The central burial from a barrow in Hubinek also yielded a ${ }^{14} \mathrm{C}$ date from the 3000-2900 BC range [Juras et al. 2018]. In this case, the burial rite recorded in the site suggests associating the grave with the older wave of migrations from the North Pontic steppe/forest steppe area.

Accepting the results for barrow 1 at Średnia as correct, one should assume a long duration of the earliest CWC phase in south-eastern Poland: from around $3000 / 2900 \mathrm{BC}$ to ca. $2600 \mathrm{BC}$ (as suggested by dendrochronology) or to ca. 2700 $\mathrm{BC}$ (assuming that the youngest among barrow graves can be assigned to a later phase, defined as "Central European horizon" for example). In light of the Średnia case, one should also consider a possibility of sub-dividing the materials within 
the 3000-2600 BC range. The central grave in this barrow contained a burial which was exceptional in terms of both the orientation and position of the body, and the grave goods. It is worth noting that the body was placed on the left side, with the head to the east. The burial was furnished with a vessel (a broadmouthed beaker) which reveals stylistic references both to artefacts of type A and to forms linked with the GAC. Therefore, the burial from Średnia can be seen as a reflection of an exceptionally early cultural transformation towards the Old Corded horizon. Perhaps it is exactly because of this early chronological position that classic attributes of the older CWC horizon are absent in the burial rite here.

Relatively early dates were also obtained for barrows A and B at Bierówka [Gancarski, Machnikowie 1986; 1990]. The first barrow, as in the case of the Średnia grave, produced two considerably diverging results. Assuming they are parallel, with a low compliance threshold, we arrive at a range of 2891-2706 BC (Fig. 7). This is also relatively early for a CWC feature, although the younger section of this range already overlaps with the dating of the oldest phase from a pan-European perspective [cf. Włodarczak 2007]. Artefacts recovered from the barrow reveal traits of horizon A [Machnik 1998: 107; Jarosz 2012: 329]. Two results available for barrow B point to a similar, although slightly broader range (2851-2504 BC - function R_Combine). The central burial was placed in a wooden chest, with the body aligned along the W-E axis, which is characteristic of the older phase of CWC. It seems most likely that the two closely situated barrows from Bierówka, sharing similar parameters of the mounds and traits of central burials, represent a unique complex associated with the oldest stage of CWC development in Lesser Poland. The low precision of the results allows the age of this complex to be only estimated at a generalised, rather broad range of ca. 2850-2700 BC.

The barrow in Wola Węgierska [Machnik, Sosnowska 1998] produced dates analogical to those from CWC graves in the Rzeszów Foothills: ca. 2500-2300 BC. This data proves contemporaneity of niche grave cemeteries at Święte, Mirocin, and Szczytna with a number of barrow graves, including the barrow clusters at Średnia and Wola Węgierska some $20 \mathrm{~km}$ from Święte. This indicates the overlapping of two "horizons": barrow and niche grave, at the same time confirming the correctness of typological conclusions, as artefacts from late barrows find analogies in materials from niche graves. The number of barrow graves in Lesser Poland furnished with artefacts analogical to those from niche graves has risen considerably due to discoveries made over recent years. One should mention here, among others, features from Ulów and Sługocin in the Lublin region [Niezabitowska-Wiśniewska, Wiśniewski 2011; Bienia et al. 2016]. In the absence of good absolute age determinations, one can only assume that the majority of these features most likely come from the turn of the older and younger CWC phases, which is from ca. $2600-2500 \mathrm{BC}$. 
Radiocarbon age determinations obtained for CWC graves from Roztocze

\begin{tabular}{|l|l|l|l|l|l|}
\hline Site & Feature no. & Lab. no. & Age ${ }^{14}$ C BP & $\begin{array}{l}\text { Calendar age } \\
\text { BC (68.2\%) }\end{array}$ & Literature \\
\hline $\begin{array}{l}\text { Brzezinki, } \\
\text { kurgan I }\end{array}$ & $?$ & Bln-... & $4030 \pm 100$ & $2857-2462$ & $\begin{array}{l}\text { Machnik, } \\
\text { Scibior } 1991\end{array}$ \\
\hline $\begin{array}{l}\text { Brzezinki, } \\
\text { kurgan I }\end{array}$ & $?$ & Bln-... & $3870 \pm 100$ & $2472-2202$ & $\begin{array}{l}\text { Machnik, } \\
\text { Scibior } 1991\end{array}$ \\
\hline $\begin{array}{l}\text { Brzezinki, } \\
\text { kurgan III }\end{array}$ & $?$ & Bln-... & $4100 \pm 100$ & $2866-2500$ & $\begin{array}{l}\text { Machnik, } \\
\text { Scibior } 1991\end{array}$ \\
\hline $\begin{array}{l}\text { Lukawica, } \\
\text { kurgan K }\end{array}$ & $?$ & Bln-... & $3800 \pm 100$ & $2453-2058$ & $\begin{array}{l}\text { Machnik, } \\
\text { Scibior 1991 }\end{array}$ \\
\hline \begin{tabular}{l} 
Ulów \\
\hline
\end{tabular} & Poz-73135 & $4045 \pm 35$ & $2621-2491$ & $\begin{array}{l}\text { Moskal del } \\
\text { Hoyo } \text { et al. } \\
\text { 2017 }\end{array}$ \\
\hline
\end{tabular}

\section{CHRONOLOGICAL RELATION TO CWC CEMETERIES FROM OTHER REGIONS OF SOUTH-EASTERN POLAND}

Apart from the Subcarpathian zone, concentrations of CWC sepulchral finds in south-eastern Poland which are the subject of the presented chronometric analyses also come from loess uplands of western Lesser Poland, the Sandomierz Upland, and the broadly understood Lublin region. In the latter area, barrow clusters in the Sokal Ridge and in the Roztocze region are of particular importance.

The barrow cluster near Narol in Roztocze, known as the Lubaczów cluster [Machnik 1966], is the closest to Święte, being situated approx. $60 \mathrm{~km}$ to the north. Barrows at Brzezinki and Łukawica belonging to this cluster produced four dates, although they are burdened with significant standard errors and are therefore unsuitable for comparison with the Subcarpathian materials. The context of acquisition of the charcoal samples from which these dates were obtained is also unknown. Given the typological and technological similarities in ceramic materials between the Lubaczów cluster and the Święte cemeteries, understanding the chronological relation between these two clusters is important. These similarities are seen primarily in finds from graves secondarily dug into Lubaczów barrows.

The chronological diversity of graves from the Lubaczów barrows is confirmed by comparative data - quite abundant today - from other regions. In their context, typological differences between materials from central graves and from features dug into barrow mounds (as in the case of barrow III at Brzezinki) become very clear. However, in the discussed cluster we also have inventories of central graves which show resemblance to materials from niche graves, including to artefacts 
T a b | e 5

Radiocarbon age determinations for CWC graves from the Sokal Ridge [after Machnik et al. 2009]

\begin{tabular}{|c|c|c|c|c|}
\hline Site & Feature no. & Lab. no. & Age ${ }^{14} \mathrm{C}$ BP & $\begin{array}{l}\text { Calendar age } \\
\text { BC }(68.2 \%)\end{array}$ \\
\hline $\begin{array}{l}\text { Hubinek, site } 3 \text {, } \\
\text { kurgan } 1\end{array}$ & 2 & Ki-6889 & $3995 \pm 55$ & $2617-2462$ \\
\hline $\begin{array}{l}\text { Hubinek, site 3, } \\
\text { kurgan } 1\end{array}$ & 3 & Ki-6890 & $4070 \pm 60$ & $2850-2492$ \\
\hline $\begin{array}{l}\text { Klekacz, site 10, } \\
\text { kurgan } 1\end{array}$ & 1 & Poz-25614 & $4045 \pm 35$ & $2621-2491$ \\
\hline $\begin{array}{l}\text { Lubcze, site 2, } \\
\text { kurgan } 2\end{array}$ & 1 & Ki-6297 & $4210 \pm 60$ & $2899-2681$ \\
\hline $\begin{array}{l}\text { Lubcze, site 2, } \\
\text { kurgan } 2\end{array}$ & 2 & Ki-6298 & $4160 \pm 50$ & $2874-2675$ \\
\hline $\begin{array}{l}\text { Lubcze, site } 37 \text {, } \\
\text { kurgan } 1\end{array}$ & 3 & Ki-6300 & $4050 \pm 55$ & $2833-2486$ \\
\hline $\begin{array}{l}\text { Machnówek, site } \\
1, \text { kurgan } 1\end{array}$ & 8 & Poz-25616 & $3940 \pm 35$ & $2546-2348$ \\
\hline $\begin{array}{l}\text { Nedeżów, site 22, } \\
\text { kurgan } 2\end{array}$ & 1 & Ki-6894 & $4020 \pm 55$ & $2619-2471$ \\
\hline $\begin{array}{l}\text { Nedeżów, site 22, } \\
\text { kurgan } 2\end{array}$ & 2 & Ki-6895 & $3940 \pm 50$ & $2558-2346$ \\
\hline $\begin{array}{l}\text { Wierszczyca, site } \\
1, \text { kurgan } 1\end{array}$ & 2 & Ki-6301 & $4305 \pm 45$ & $3010-2884$ \\
\hline $\begin{array}{l}\text { Wierszczyca, site } \\
30, \text { kurgan } 1\end{array}$ & 3 & Ki-6891 & $4125 \pm 50$ & $2862-2620$ \\
\hline $\begin{array}{l}\text { Wierszczyca, site } \\
31 \text {, kurgan } 1\end{array}$ & 2 & Ki-8955 & $3845 \pm 50$ & $2437-2207$ \\
\hline $\begin{array}{l}\text { Wierszczyca, site } \\
31 \text {, kurgan } 1\end{array}$ & $4 / 5$ & $\mathrm{Ki}-8952$ & $3850 \pm 60$ & 2453-2209 \\
\hline $\begin{array}{l}\text { Wierszczyca, site } \\
31 \text {, kurgan } 1\end{array}$ & 6 & Ki-8953 & $3850 \pm 50$ & $2453-2209$ \\
\hline
\end{tabular}

discovered in the Święte cemeteries. This is best demonstrated by the finds from the central burial of barrow I at Brzezinki [Machnik 1966: pl. XIX: 2], which contained an amphora and beakers characteristic of the younger CWC phase in Lesser Poland (including Święte sites 11 and 15). Thus, barrow I at Brzezinki is a good piece of evidence for a late chronology of some of Lesser Polish barrows. Typologically similar (= chronologically late) inventories of central graves are also known from Ulów in Roztocze [Niezabitowska-Wiśniewska, Wiśniewski 2011] and from Sługocin in the Nałęczów Plateau [Bienia et al. 2016]. Therefore, the large spread of the dates obtained for the Lubaczów barrows (Table 4) may simply reflect the diversified chronology of the graves, with both the older and younger CWC phases represented. 
Ta b I e 6

Radiocarbon age determinations for CWC graves from the Lublin Upland

\begin{tabular}{|l|l|l|l|l|}
\hline Site & Feature no. & Lab. no. & Age ${ }^{14}$ C BP & $\begin{array}{l}\text { Calendar age } \\
\text { BC (68.2\%) }\end{array}$ \\
\hline $\begin{array}{l}\text { Lublin-Rury } \\
\text { (Gliniana str.) }\end{array}$ & & Poz-58116 & $4115 \pm 30$ & $2855-2620$ \\
\hline $\begin{array}{l}\text { Lublin-Sławinek, } \\
\text { site 3 }\end{array}$ & 60 & Poz-58115 & $3895 \pm 30$ & $2460-2346$ \\
\hline $\begin{array}{l}\text { Lublin-Sławinek, } \\
\text { site 3 }\end{array}$ & 59 & Poz-58114 & $3870 \pm 30$ & $2454-2293$ \\
\hline Lagiewniki & & Poz-58106 & $3770 \pm 35$ & $2278-2138$ \\
\hline
\end{tabular}

In the Lublin region, ${ }^{14} \mathrm{C}$ dates were obtained for $\mathrm{CWC}$ graves from the Sokal Ridge and for a few graves from the Nałęczów Plateau³. Barrows from the Sokal Ridge produced the second largest - after western Lesser Poland - series of radiocarbon age determinations (Table 5) [Machnik 1999; Machnik et al. 2009: 221, Table 20]. They were obtained in the Kiev laboratory and included results pointing to a very early chronology of some graves (e.g. graves from barrow 1 at Wierszczyca and barrow 2 at Łubcze). Only a portion of these results corresponds with the dates available for the Święte cemeteries and the neighbouring sites in the Rzeszów Foothills. Two AMS determinations obtained in the Poznań laboratory fit well into the series of results from Subcarpathian sites. The central grave at Klekacz produced a date that, in accordance with the typological analysis, could be referred to the younger section of the older CWC phase. The second result is also important. It was obtained for grave 8 at Machnówek - a niche grave in which a small beaker typical of the Middle Dnieper culture was found. The date suggests that elements of this culture appeared either in the early or middle stage of the late phase of CWC in Lesser Poland (which means perhaps yet before the middle of the 3rd millennium BC). The appearance of Middle Dnieper culture vessels in CWC graves was dated to a similar period based on radiocarbon dates from the Kiev laboratory [Kadrow 2003: 244-245].

Some of the graves secondarily dug into barrows from the Sokal Ridge obtained dates pointing to a range of $2800-2600 \mathrm{BC}$, i.e. to the older phase of CWC (Table 5). Here belongs, for example, grave 2 from barrow 2 at Łubcze - a niche grave containing pottery with distinct traits of the late, or even final phase of CWC in Lesser Poland [Machnik et al. 2009: 49, Fig. 35]. This situation is analogical to that recorded for CWC finds from the Lesser Poland Upland discussed further in the text: some of the dates from the Kiev laboratory point to a slightly older age than series of dates obtained in other laboratories [Włodarczak 2007: 59; 2009].

\footnotetext{
${ }^{3}$ Radiocarbon dates of the graves from Lublin upland have been received thanks to the grant of the National Science Centre OPUS no. 2012/05/B/HS3/04138.
} 
T a b I e 7 Radiocarbon age determinations for CWC graves from loess uplands in western Lesser Poland and from the Sandomierz Upland (only the determinations obtained with the AMS technique

\begin{tabular}{|c|c|c|c|c|}
\hline Feature & Lab. no. & Age ${ }^{14} \mathrm{C}$ BP & $\begin{array}{l}\text { Calendar age } \\
\mathrm{BC}(68.2 \%)\end{array}$ & Literature \\
\hline \multicolumn{5}{|c|}{ Bronocice 1} \\
\hline XI & AA-90116 & $4000 \pm 40$ & $2569-2474$ & Kruk et al. 2018 \\
\hline \multicolumn{5}{|c|}{ Gabułtów 1} \\
\hline 1 & Poz-9451 & $4115 \pm 30$ & $2740-2579$ & Jarosz, Włodarczak 2007 \\
\hline 2 & Poz-9452 & $3930 \pm 35$ & $2476-2347$ & Jarosz, Włodarczak 2007 \\
\hline \multicolumn{5}{|c|}{ Łapszów 1} \\
\hline 1 & Poz-9457 & $3870 \pm 35$ & $2455-2293$ & Jarosz, Włodarczak 2007 \\
\hline \multicolumn{5}{|c|}{ Malżyce, 30, barrow 1} \\
\hline 2 & Poz-59407 & $3860 \pm 35$ & $2454-2236$ & Szczepanek et al. 2018 \\
\hline 4 & Poz-90765 & $3910 \pm 30$ & $2467-2348$ & Szczepanek et al. 2018 \\
\hline 5 & Poz-90767 & $3870 \pm 30$ & $2454-2293$ & Szczepanek et al. 2018 \\
\hline 7 & Poz-90768 & $3875 \pm 35$ & $2454-2298$ & Szczepanek et al. 2018 \\
\hline \multicolumn{5}{|c|}{ Malżyce, 30, barrow 2} \\
\hline 10 & Poz-27990 & $3940 \pm 40$ & $2548-2348$ & Jarosz et al. 2009 \\
\hline 11 & Poz-27991 & $3910 \pm 35$ & $2468-2346$ & Jarosz et al. 2009 \\
\hline 12 & Poz-27992 & $3930 \pm 40$ & $2477-2346$ & Jarosz et al. 2009 \\
\hline \multicolumn{5}{|c|}{ Pełczyska 6} \\
\hline $32 / 2002$ & Poz-12580 & $3880 \pm 35$ & $2456-2307$ & Jarosz, Włodarczak 2007 \\
\hline \multicolumn{5}{|c|}{ Smroków 17} \\
\hline 1 & Poz-9600 & $3950 \pm 40$ & $2564-2350$ & Jarosz, Włodarczak 2007 \\
\hline 2 & Poz-9588 & $3885 \pm 35$ & $2457-2311$ & Jarosz, Włodarczak 2007 \\
\hline 10 & Poz-9584 & $3905 \pm 35$ & $2466-2346$ & Jarosz, Włodarczak 2007 \\
\hline \multicolumn{5}{|c|}{ Szarbia 9} \\
\hline 3/VIII & Poz-9581 & $3840 \pm 35$ & $2397-2207$ & Jarosz, Włodarczak 2007 \\
\hline \multicolumn{5}{|c|}{ Wilczyce 10} \\
\hline 28 & Poz-80189 & $3960 \pm 30$ & $2566-2458$ & Włodarczak et al. 2016 \\
\hline \multicolumn{5}{|c|}{ Zielona 3} \\
\hline 3 & Poz-9585 & $3955 \pm 35$ & $2565-2351$ & Jarosz, Włodarczak 2007 \\
\hline 7 & Poz-9577 & $3895 \pm 30$ & $2460-2346$ & Jarosz, Włodarczak 2007 \\
\hline \multicolumn{5}{|l|}{ Żuków } \\
\hline $1[2]$ & Poz-9583 & $3885 \pm 35$ & $2457-2311$ & Jarosz, Włodarczak 2007 \\
\hline $3[4]$ & Poz-9579 & $3835 \pm 35$ & $2344-2206$ & Jarosz, Włodarczak 2007 \\
\hline
\end{tabular}


Ta b I e 8

Radiocarbon age determinations obtained for CWC barrows graves from western Lesser Poland

\begin{tabular}{|l|l|l|l|l|l|}
\hline Site & Feature no. & Lab. no. & Age ${ }^{14} \mathbf{C ~ B P}$ & $\begin{array}{l}\text { Calendar age } \\
\text { BC (68.2\%) }\end{array}$ & Literature \\
\hline Gabułtów & 1 & Poz-9451 & $4115 \pm 30$ & $2740-2579$ & $\begin{array}{l}\text { Jarosz, Wło- } \\
\text { darczak 2007 }\end{array}$ \\
\hline Koniusza & 14 & GrN-12517 & $4000 \pm 30$ & $2567-2477$ & $\begin{array}{l}\text { Tunia, Wło- } \\
\text { darczak 2002 }\end{array}$ \\
\hline Lelowice & & Ki-9530 & $4110 \pm 100$ & $2870-2573$ & Rodak 2012 \\
\hline $\begin{array}{l}\text { Miernów, } \\
\text { barrow 2 }\end{array}$ & 2 & K-1837 & $3960 \pm 100$ & $2618-2293$ & $\begin{array}{l}\text { Kempisty } \\
1978\end{array}$ \\
\hline $\begin{array}{l}\text { Miernów, } \\
\text { barrow 2 }\end{array}$ & 2 & Ki-5833 & $4105 \pm 35$ & $2850-2580$ & $\begin{array}{l}\text { Włodarczak } \\
\text { 2001 }\end{array}$ \\
\hline
\end{tabular}

The few results available for CWC cemeteries from the eastern part of the Nałęczów Plateau (Table 6) are consistent with the data from the Subcarpathian area [Włodarczak 2016]. Certain interpretational difficulty is only posed by an exceptionally early date obtained for a grave from Lublin-Rury. It was, however, obtained from materials retrieved from a damaged grave (of unknown construction; the recovered artefacts point rather to the younger phase of CWC). It is worth noting one of the latest results for CWC in Lesser Poland, obtained for a grave from Lagiewniki (2278-2138 BC). In this case, the late chronology is confirmed by both the bi-ritual nature of the burial, and the nature of the grave goods. Dates obtained for graves from Lublin-Sławinek correspond with the chronology of the Święte cemeteries.

Loess uplands on the left bank of the Vistula River abound in CWC finds, and were the first region to have attracted intensive chronometric research [e.g. Machnik, Ścibior 1991; Włodarczak 1998; 2001; 2006; 2013; Jarosz Włodarczak 2007]. The region can be used as an example demonstrating the need to verify older series of ${ }^{14} \mathrm{C}$ dates by new results, obtained with upgraded techniques and having greater precision [Włodarczak 2008; 2009; a similar approach to finds from Central Germany: Fröhlich, Becker 2015]. In the 1990s the first longer series of results was produced for the Żerniki Górne cemetery [Włodarczak 1998]. These dates were accepted at that time as the benchmark for CWC chronometry in Lesser Poland. These results, however, applied to niche graves of the Kraków-Sandomierz group only. Despite the above, some of these dates pointed to an early age of the finds, corresponding with the period of the earliest barrow graves. In later years, such early determinations, within a generalised period of 2900-2600 BC, were obtained for several other graves in the Kraków-Sandomierz area, for example for Zielona, Kraków-Zesławice, and Samborzec [Włodarczak 2006]. A new series of AMS results obtained in the Poznań Radiocarbon Laboratory over the last 10 years 
allowed for verification and rejection of these previous early dates for the KrakówSandomierz group (Table 7). The new results indicate a parallel age of cemeteries in the western and eastern parts of Lesser Poland, with the dates similar to those from Święte and the Rzeszów Foothills. Given the already assured repeatability of ${ }^{14} \mathrm{C}$ age determinations for niche graves in the Kraków-Sandomierz region, the biggest issue still remaining to be resolved is the chronology of barrows in western Lesser Poland, for which only single results are available (only 5 determinations from four different laboratories - Table 8).

\section{TYPOCHRONOLOGICAL STUDIES AND THE ABSOLUTE CHRONOLOGY}

It is worth noticing the concordance of the results of absolute age determination with the relative chronology of Final Eneolithic materials established on the basis of typological analysis of grave furnishings (primarily pottery) and traits of burial rites (e.g. grave construction and body position). For CWC, this is typically verified by testing the correctness of chronological models which are based on classical, benchmark studies of regions rich in sepulchral finds, in particular studies which have larger than local influence which provide a repeated, sometimes enriched, long-lasting pattern [e.g. Glob 1944; Struve 1955; Buchvaldek 1967]. For Lesser Poland, such a benchmark is provided by Jan Machnik's study [1966], whose main points were developed in later typochronological studies [first of all: Kempisty 1978; Włodarczak 2006]. It needs to be emphasised that these models only drew from stratigraphic observations to a small extent. Stratigraphy only provided grounds for concluding about the anteriority of at least some barrow graves ("early Corded") in relation to cemeteries with niche graves (younger CWC). Some of the barrow graves also revealed stylistic connections with materials described as "Pan-European" (= "type A" or early Corded). This early position of the "A type" style later found clear confirmation in dendrochronologically dated CWC materials from sub-Alpine lake settlements [for recapitulation see: Stöckli 2009; cf. Włodarczak 2007].

Chronological division of materials assigned to the younger phase, which in practice means the vast majority of the materials, is a more difficult task. Among graves from Lesser Poland, regarded as older were materials in which scholars suspected traits either of the older CWC horizon [phases II-IIIA acc. to Włodarczak 2006], or of earlier Eneolithic cultures, e.g. the Funnel Beaker culture [the concept of a horizon with vessels of the Książnice Wielkie type: Machnik 1966]. A later chronological position, on the other hand, was applied to inventories in 
which scholars believed to notice traits characteristic of the Bell Beaker culture or the oldest phase of the Mierzanowice culture (e.g. P. Włodarczak's concept of subphase IIIC). Attempts were made to create typological developmental sequences for selected artefact categories, e.g. stone battle-axes. Models created in this manner (primarily Machnik 1966; Kempisty 1978; Włodarczak 2006) have not as yet been successfully verified by means of stratigraphic evidence or absolute dates.

There are two basic aspects to the critical analysis of the relation between absolute age determinations and results of typological analyses: (1) comparison of the age of the finds from the older phase and the younger phase, and (2) chronological relations within the clearly predominant group of finds linked with the younger phase.

1. In Lesser Poland, the older group of finds was defined by materials having stylistic associations with the early Corded style (i.e. "Pan-European horizon"/"horizon A") [Machnik 1966] and later refined by distinguishing finds belonging to the "Central European horizon" (younger phase of the older stage of CWC development) [Machnik 1979; cf. also Kempisty 1978]. However, the model positing a simple succession of finds from the younger stage after those from the older stage was challenged when late radiocarbon dates were obtained for graves from Lubaczów group barrows (previously regarded as early Corded) [Machnik, Ścibior 1991: 50], and next for some barrows from the Subcarpathian area as well (e.g. Krajowice in the Strzyżów Foothills, or Bykiv in the western fringes of Ukraine). It was demonstrated at that time that outside western Lesser Poland (the KrakówSandomierz group) the early Corded style continued longer, until the beginnings of the Bronze Age [Machnik 1994; 1997]. Then results of absolute age determinations called the validity of models based on pottery typologies into question. Similar results were obtained in other parts of Europe, and attempts to reconcile the relative and absolute chronologies included a conclusion positing a "survival" of early Corded style in younger stages of Final Eneolithic, or explanations involving other (other than chronological) factors affecting typological diversity of CWC amphorae and beakers [Müller 1999: 84; 2000: 67].

On the other end, some finds from Lesser Poland, typologically dated to the younger stage of the Final Eneolithic, produced very early ${ }^{14} \mathrm{C}$ dates, in some cases even pre-dating early CWC barrows (grave 3 at Zielona and grave 2 from barrow 1 at Wierszczyca, site 1). These results were used in some chronological models that did not take relative chronology into account, where they represented the oldest CWC horizon [Furholt 2003; 2004: 482-485]. Renewed dating with the more precise AMS technique, performed for some of the samples, did not confirm the exceptionally early chronology of the niche graves in question [Włodarczak 2007; 2009] and demonstrated that they are contemporary with other graves of this type.

Thanks to a long series of radiocarbon dates obtained in the Poznan laboratory (a total of 89 results for graves from Lesser Poland, as of the end of 2018), it has become clear today that barrow graves are generally older and that CWC cemeter- 
ies with niche graves appeared only in the younger stage of the Final Eneolithic (ca. 2600/2500 BC). What remains unclear, on the other hand, are chronometric conclusions concerning the late stage of the barrow horizon, and its possible contemporaneity with cemeteries representing the younger CWC phase. This contemporaneity is suggested by examples of niche barrow graves of the Lesser Polish type in the Kraków-Sandomierz group (Miernów, barrow II, and Zielona, site 3), as well as some pit graves in barrows in eastern Lesser Poland, containing objects characteristic of the late phase (e.g. Ulów in Roztocze and Sługocin in the Lublin Upland).

2. The problem with assemblages from the younger stage of CWC development is that they cover a very broad range of 2600-2200 BC, although most likely their vast majority actually comes from a narrower timespan of ca. 2500-2400/2300 BC. In models based on relative chronology the finds in question were usually divided into stages, e.g. IIa and IIb [Machnik 1966], IIIa and IIIb [Machnik, Ścibior 1991], or IIb, IIIa, IIIb, and IIIc [Włodarczak 2006]. Yet it proved impossible to demonstrate the validity of these divisions by absolute age determinations. The ${ }^{14} \mathrm{C}$ results do not show any tendency for clustering in accordance with the suggestions derived from the relative chronology. However, the analysed timespan is relatively short and, without additional arguments (e.g. stratigraphic ones), radiocarbon age determinations do not allow for its sub-division, due to certain limitations of the method.

The nature of the calibration curve makes it difficult to determine the marginal dates of the range within which finds from the younger $\mathrm{CWC}$ phase place. The flattening of the curve is particularly clear for the period of 2450-2250 BC, which corresponds with the close of the CWC occupation. This often results in extending the lifespan of the CWC model and suggesting its contemporaneity with the Bell Beaker culture and the earliest phases of the Mierzanowice culture in Lesser Poland. Yet, the vast majority of the dates can be referred to before $2400 \mathrm{BC}$, as evidenced by the results of radiocarbon age determinations for the Święte cemeteries, presented above.

The determination of the beginning of the younger phase is slightly less of a problem. The older sections of relevant AMS dates suggest a range of ca. 2550$-2450 \mathrm{BC}$. A period preceding this range is only indicated by the above-mentioned less precise determinations obtained in the 1990s - which have been rejected here as less credible (the decision to reject them is also supported by the results of renewed dating of some of the samples). Barrow graves with inventories having analogies in materials from the beginning of the younger CWC phase date to the 26th century BC as well. Grave 14 from Koniusza in western Lesser Poland, with a Ślęża type axe and a rich collection of tools, is a good example in this context [Tunia, Włodarczak 2002: 47, 50]. 
5. COMPARISON OF AGE DETERMINATIONS FOR EARLY BRONZE AGE CULTURES FROM THE NORTH-WEST PONTIC AREA AND FOR LESSER POLISH CWC

From the perspective of research on relationships between CWC communities in Lesser Poland and the north-west Pontic area, a comparison with chronometric data concerning the Yamnaya culture (YC) and the Catacomb culture (CC) is very important. The numerous age determinations available for these two cultural phenomena generate similar problems as the results obtained for CWC in Lesser Poland. Taking all the available dates into account results in improbably broad timeframes, and the approach has therefore been subject to critical interpretations [e.g. Telegin et al. 2003: 142-148, Table 1; Chernykh, Orlovskaya 2004: 86-92, Tables 1-2; Rassamakin, Nikolova 2008: 81-87, Table 1]. These problems stem, among others, from uncertain sample contexts and incomplete source publications. It was also noticed that some determinations obtained from charcoals had produced older results [Rassamakin, Nikolova 2008: 62-63]. Obtained in the 21 st century and better documented, radiocarbon age determinations such as those from "Tarasova Mogila" at Orechov [Govedarica et al. 2006], or barrow 24 at Vinogradnoye [Görsdorf et al. 2004] have contributed to a better understanding of the dynamics of cultural development. Also of importance is the acquisition of the first dendrochronological dates supplementing the series of ${ }^{14} \mathrm{C}$ dates for "Sugokleyska Mogila" barrow at Kirovograd [Nikolova, Kaiser 2009, Nikolova 2012]. Another contribution to refining the chronometric data has come from a research project on barrows in the Yampil region - the north-westernmost barrow group on the left - Podolian - bank of the Dniester River [Goslar et al. 2015]. The focus of the project was the analysis of contacts between forest-steppe/steppe communities and those from the central European cultural circle [Kośko (Ed.) 2015]. Radiocarbon dates obtained for barrows from the Jampol cluster correspond well with other recent results. They unambiguously show that some YC graves pre-date the older CWC phase in central Europe [Goslar et al. 2015: 281-283]. The younger YC stage chronologically corresponds with barrow graves from older CWC horizons. This chronological order is confirmed by the discovery of an amphora of type A in grave 2/6 at Porohy, Yampil raion, dug into a barrow mound [Harat et al. 2014: 87, Fig. 2.3.4:9].

The comparison of radiocarbon dates for CWC in Lesser Poland and YC in the north-west Pontic area results in an important and previously unexpected conclusion. ${ }^{14} \mathrm{C}$ dates from the Święte sites and throughout the Rzeszów Foothills unambiguously show CWC niche graves to be younger than the finds from the Yampil region and the majority of other YC graves from the north-west Pontic zone. The determination of the age of these niche graves at the years after ca. 2600/2550- 
$-2300 / 2200 \mathrm{BC}$ (with the majority falling within the 2500-2300 BC range) indicates that the younger $\mathrm{CWC}$ phase dates to a period when the $\mathrm{CC}^{4}$ rite had already come to prevail in the forest-steppe and steppe areas.

The demonstration of the parallel spread of the specific catacomb construction and several other traits of funerary rituals in Lesser Poland and in the CC range opens up an interesting interpretational perspective. Absolute age determinations for early $\mathrm{CC}$ phases are available primarily for the Donets $\mathrm{CC}$, and they suggest dating these phases to 2800-2500 BC [Kaiser 2009: 63-65]. This means that this stage was parallel with the late stage of YC development, and at the same time with the older phase of CWC. Therefore, only the closing stages of the early CC phase could have been contemporary with the cemeteries at Święte, and with the niche grave phase in Lesser Poland in general. Of importance is the conclusion about a similar age of the determinations obtained for early $\mathrm{CC}$ and for niche graves of the Złota culture from Lesser Poland [cf. Włodarczak 2008: 557-559; 2013: 379-381; Wilk 2013: 334]. The possibility of synchronisation with early CC corroborates the interpretation of the genesis of Złota type assemblages as resulting from mutual relationships between GAC and communities from the north-western Pontic area - the late phase (C/II) of the Trypilia culture and YC [cf. Włodarczak 2008; 2014]. A weak point of this reconstruction remains the still-insufficient chronometric research of $\mathrm{CC}$ finds from north-west Pontic forest-steppe areas, which means from the part of $\mathrm{CC}$ range closest to Lesser Poland. The finds from that area are sparse, and the lack of rich burial complexes makes them much less distinct than the Donets and Ingul clusters of CC [cf. e.g. Toschev 2013; Kaiser 2003; Ivanova 2013; Otroshchenko 2013]. Graves with burials in supine position, akin to those from the Ingul cluster, prevail here, while features confidently linked with the older $\mathrm{CC}$ phase (such as the grave from Ocniţa, Kamienka region [Klochko 1990] are few.

"T-shaped" niche/catacomb graves, specific for Lesser Polish CWC and classic CC [e.g. Kaiser 2003, Ślusarska 2006], became widespread around the middle of the 3rd millennium BC. It was roughly at the same time when artefacts testifying to connections with the territories to the east of Lesser Poland started to appear in CWC graves. These objects revealed traits of the Middle Dnieper culture and late YC/CC [for the cemeteries at Święte see: Janczewski et al. 2018; Olszewski, Włodarczak 2018].

\footnotetext{
${ }^{4}$ Presenting the phenomenon of the "Catacomb culture" and the most relevant terminology is beyond the scope of this paper [for review of discussion see: Otroshchenko 2013: 21-23].
} 


\section{RELATION TO CEMETERIES OF THE MIDDLE DNIEPER CULTURE}

The investigation of cemeteries in Roztocze and the Sokal Ridge brought to scholarly attention the presence in grave inventories of vessels revealing traits of the Middle Dnieper culture [e.g. Machnik, Pilch 1997; Machnik 1999; Machnik et al. 2001; 2009]. Chronometric data [Machnik 1999] suggested dating these assemblages to around the middle of the 3rd millennium BC [Kadrow 2003]. Single new results obtained with the AMS technique for graves containing Middle Dnieper culture vessels confirmed these previous conclusions. Chronometric data for the Święte cemeteries, where pottery forms with references to the Middle Dnieper culture were present, are also of importance in this context [Janczewski et al. 2018]. Another important contribution comes from grave 54 at Mirocin, site 24, which contained a typical hourglass-shaped beaker [Machnik et al. 2019], and which has been dated (human bone sample) to 2546-2348 BC. All the above information allows for a conclusion that the appearance of Middle Dnieper elements took place at the stage of crystallisation of attributes typical of the classic (younger) CWC phase in Lesser Poland, including the Kraków-Sandomierz group, the Sokal group, and the Subcarpathian cemeteries with niche graves which are a particular focus of this study.

However, the above data are difficult to compare with the genetic-chronological model of the Middle Dnieper culture development. Absolute age determinations available for graves of this culture are few and apply to the upper Dnieper basin in Belarus, first of all to the Ragachov region [Krywalcewicz 2007: 66-69], while no dates have as yet been obtained for diagnostic assemblages from the Ukrainian cluster on the middle Dnieper River [Bunyatyan 2008: 10]. If we assume that the data from the upper Dniester area are representative for the chronometry of the Middle Dnieper culture, we arrive at a long timeframe spanning from ca. 2800/2600 BC until the mid-2nd millennium BC. This wide dispersal of results should, however, be verified in future using more precise techniques. It is worth noticing the earliest dates for Prorva 1 cemetery, which point to the first half of the 3rd millennium BC. If they are correct, they imply that the initial stage of the Middle Dnieper culture pre-dates the younger CWC phase in Lesser Poland. However, the author of the research himself prefers to establish the beginning of the earliest phase at this site at around $2500 \mathrm{BC}$, as indicated by other ${ }^{14} \mathrm{C}$ dates [Krywalcewicz 2007: 70]. In this approach, the age of flat cemeteries of the Middle Dnieper culture corresponds with CWC niche graves in Lesser Poland, and at the same time with the period when CC rites started to dominate in the north Pontic zone. What remains unknown, however, is the chronology of barrow cemeteries with inhumation burials, both in the upper Dnieper area (e.g. Khodosovichi-Moshka) and in the middle Dnieper area (e.g. Jackowica, nowadays Dolynka, barrow 29). Given the presence of early Corded elements in 
the Middle Dnieper culture, these cemeteries should most likely be referred to a horizon of CWC phase I - late phase YC, which is ca. 2800-2600 BC.

In light of the above chronological conclusions, the relations between CWC in Lesser Poland and the Middle Dnieper culture are clearly detectable at the beginning of the second half of the 3rd millennium $\mathrm{BC}$, which is parallel with the beginnings of the Donets and Ingul variants of CC. However, reliable data for assessing the connections in the earlier period, corresponding with the Pan-European horizon of CWC, are still lacking.

7. SUMMARY

The large number of high-quality radiocarbon age determinations for CWC graves in Lesser Poland has made it possible to set the Święte cemeteries within a chronometric sequence of cultural transformations, both on the micro- and macro-regional scales (SE Poland). Future analyses can be expected to refine chronometric data for cultural phenomena from territories to the east of Lesser Poland, associated with the Corded complex (first of all: the upper Dniester CWC and the Middle Dniester culture) and the steppe cultural circle (late YC, and first of all CC in the north-west Pontic area).

The series of dates for the Święte cemeteries has demonstrated a parallel cultural development in the Kraków-Sandomierz, Lublin, Sokal, and Subcarpathian areas. Beginning from the 26th century BC, deceased were predominantly buried in niche graves in all these areas, and a specific set of rules concerning body position and grave goods was observed. This tradition ceased around 2400-2300 BC (depending on the region).

Cemeteries with niche graves were contemporary with the youngest barrow burials (few?), as evidenced by the dates (Wola Węgierska) and characteristics of the furnishings of central graves.

Around 2550-2450 BC, artefacts reflecting connections with CC (perhaps also the late phase of YC) and Middle Dnieper culture communities appear in CWC graves.

The remarks presented here lead to the following conclusion: the sequence of absolute chronology for CWC graves can be synchronised with the typochronological dating, although the resulting model requires considerable refinement. Such a synchronisation makes it possible to address genetic problems concerning Final Eneolithic communities from Lesser Poland. 


\section{REFERENCES}

Bienia M., Budziszewski J., Niedźwiedź E., Niedźwiedź J., Włodarczak P.

2016 Kurhan kultury ceramiki sznurowej na stanowisku 5 w Sługocinie, pow. lubelski. In: P. Jarosz, J. Libera, P. Włodarczak (Eds) Schyłek neolitu na Wyżynie Lubelskiej, 257-286. Kraków.

Buchvaldek M.

1967 Die Schnurkeramik in Böhmen. Acta Universitatis Carolinae. Philosophica et historica. Monographia 19. Praga.

Bunyatyan K.P.

2008 Khronologiya ta periodizatsiya serednodniprovskoy kulturi pravoberezhnoi Ukraini. Arkheologiya 2/2008: 3-12.

Chernykh E.N., Orlovskaya L.B.

2004 Radiouglerodnaya khronologiya katakombnoy kulturno-istoricheskoy obschnosti (sredniy bronzovyi vek). Rossiyskaya Arkheologiya 2(2004): 15-29 .

Dębiec M., Dębiec M., Pelisiak A.

2015 Cieszacin Wielki, stan. 41, Pawłosiów, stan. 55 i Jankowice, stan. 9. Kompleks osad z epoki neolitu i wczesnej epoki brazu. Via Archaeologica Ressoviensia 9. Rzeszów.

Fröhlich M., Becker M.

2015 Typochronologische Überlegungen zu den Kulturen des Endneolithikums und den frühen Bronzezeit zwischen Saale und Unstrut im 3. Jt. v. Chr. In: H. Meller, H. W. Arz, R. Jung, R. Risch (Eds) 2200 BC - Ein Klimasturz als Ursache für den Zerfall der Alten Welt? 2200 BC-A climatic breakdown as a cause for the collapse of the old world? 7. Mitteldeutscher Archäologentag vom 23. bis 26. Oktober 2014 in Halle (Saale), 765-782. Halle (Saale).

Furholt M.

2003 Die absolutchronologische Datierung der Schnurkeramik in Mitteleuropa und Südskandinavien. Universitätsforschungen zur Prähistorischen Archäologie 101. Bonn.

2004 Entstehungsprozesse der Schnurkeramik und das Konzept eines Einheitshorizonstes. Archäologisches Korrespondenzblatt 34: 479-498. 
Gancarski J., Machnikowie A. \& J.

1986 Wyniki badań kurhanu A kultury ceramiki sznurowej we wsi Bierówka, gmina Jasło, w województwie krośnieńskim. Acta Archaeologica Carpathica 25: 57-87.

1990 Kurhan B kultury ceramiki sznurowej w Bierówce, gmina Jasło, w świetle badań wykopaliskowych. Acta Archaeologica Carpathica 29: 99-124.

Gancarski J., Valde-Nowak P.

2011 Inwentarze ,grobowe” kultury ceramiki sznurowej w nasypach kurhanów w Karpatach. In: H. Kowalewska-Marszałek, P. Włodarczak (Eds) Kurhany i obrzadek pogrzebowy w IV-II tysiącleciu p.n.e., 279-289. Kraków, Warszawa.

Glob P. V.

1945 Studier over den jyske Enkeltgravskultur. Aarborger for nordisk Oldkyndighed og Historie (1944), 15-64. København.

Goslar T., Klochko V.I., Kośko A., Włodarczak P, Żurkiewicz D.

2015 Chronometry of late Eneolithic and "Early Bronze" cultures in the middle Dniester area: investigations of the Yampil barrow Complex. Baltic-Pontic Studies 20: 256-191.

Goslar T., Kośko A.

2011 Z badań nad chronologią i topogenezą kujawskich kurhanów starosznurowych. Krusza Zamkowa, powiat Inowrocław, stanowisko 3. In: H. Kowalewska-Marszałek, P. Włodarczak (Eds) Kurhany i obrząek pogrzebowy w IV-II tysiącleciu p.n.e., 407-415. Kraków, Warszawa.

Goslar T., Klochko V.I., Kośko A., Włodarczak P., Żurkiewicz D.

2015 Chronometry of late Eneolithic and 'Early Bronze' cultures in the middle Dniester area: investigations of the Yampil Barrow Complex. Baltic-Pontic Studies 20: 256-291.

Govedarica B., Kaiser E., Rassamakin Y.Y., Samar V.A.

2006 Der Grabhügel „Tarasova Mogila” bei der Stadt Orechov. Neue Angaben zur Periodisierung und Chronologie der äneolithischen und bronzezeitlichen Steppenkulturen im Azovgebiet. Eurasia Antiqua 12: 63-112.

Görsdorf J., Rassamakin Y., Häusler A.

$2004{ }^{14} \mathrm{C}$ dating of mound 24 of the kurgan group near Vinogradnoye village, Ukraine. In: T. Higham, Bronk Ramsey C., Owen C. (Eds) Radiocarbon and archaeology. Fourth International Symposium. St Catherine's college, Oxford 9-14 April 2002, 127-134. Oxford. 
Górski J., Jarosz P., Tunia K., Wilk S., Włodarczak P.

2013 New evidence on the absolute chronology of the early Mierzanowice culture in south-eastern Poland. In: M. Bartelheim, J. Peška, J. Turek (Eds) From copper to bronze. Cultural and social transformation at the turn of the 3rd/2nd millenia B.C. in Central Europe, 105-118. Langenweissbach.

Harat K., Potupczyk M., Razumov S.

2014 Charakterystyka źródeł archeologicznych pozyskanych w latach 1984-1993. In: A. Kośko, M. Potupczyk, S. Razumow (Eds) Naddniestrzańskie kompleksy cmentarzysk kurhanowych społeczności z III i z pierwszej polowy II tysiaclecia BC w okolicach Jampola, obwód winnicki. Z badań nad północno-zachodnia rubieza osadnictwa społeczności kregu kultur wczesnobrązowych strefy pontyjskiej. Badania z lat 1984-2010. Archaeologia Bimaris - Monografie 6, 45-204. Poznań.

Hozer M., Machnik J., Bajda-Wesołowska A.

2017 Groby kultury ceramiki sznurowej i domniemane kultury mierzanowickiej w Szczytnej, pow. Jarosław - źródła, analizy, wnioski. In P. Jarosz, J. Machnik (Eds) Nekropolie ludności kultury ceramiki sznurowej z III tysiąclecia przed Chr. w Szczytnej na Wysoczyźnie Kańczuckiej. Via Archaeologica Ressoviensia 12, 7-130. Rzeszów.

Ivanova S.V.

2013 Kulturno-istoricheskie kontakty naseleniya Severo-Zapadnogo Prichernomoria v rannem bronzovom veke: Zapad-Vostok. Stratum plus 2(2004): 158-248.

Janczewski P., Kraus P., Włodarczak P.

2018 Swięte 15: cemetery of the Corded Ware culture. Baltic-Pontic Studies 23: 93-139.

Jarosz P.

2012 Wczesne etapy osadnictwa kultury ceramiki sznurowej w strefie karpackiej. Fortetsia zbirnik zapovidnika „Tustan” 2: 322-332.

Jarosz P., Mazurek M., Szczepanek A.

2018 Dobkowice, stanowiska 37 i 39, woj. podkarpackie. Osady kultury mierzanowickiej na Podgórzu Rzeszowskim. Via Archaeologica Ressoviensia 14. Rzeszów.

Jarosz P., Tunia K., Włodarczak P.

2009 Burial mound no. 2 in Malżyce, the district of Kazimierza Wielka. Sprawozdania Archeologiczne 61: 175-231. 
Jarosz P., Włodarczak P.

2007 Chronologia bezwzględna kultury ceramiki sznurowej w Polsce południowo-wschodniej oraz na Ukrainie. Przeglad Archeologiczny 55: 71-108.

Juras A., Chyleński M., Ehler E., Malmström H., Żurkiewicz D., Włodarczak P., Wilk S., Peška J., Fojtík P., Králík M., Libera J., Bagińska J., Tunia K., Klochko V.I., Dabert M., Jakobsson M., Kośko A.

2018 Mitochondrial genomes reveal an east to west cline of steppe ancestry in Corded Ware populations. Scientific Reports 8: 11603

Kadrow S.

2003 Absolute chronology of the Middle Dnieper culture between the upper Bug, Vistula and Dniester rivers. Baltic-Pontic Studies 12: 241-246.

Kaiser E.

2003 Studien zur Katakombengrabkultur zwischen Dnepr und Prut. Archäologie in Eurasien 14. Mainz.

2009 Problemy absolutnogo datirovaniya katakombnoy kultury Severnogo Prichernomoria. Tyragetia (serie nouă) 3 (18/1): 59-70.

Kempisty A.

1978 Schyłek neolitu i początek epoki brązu na Wyżynie Małopolskiej w świetle badań nad kopcami. Warszawa.

Klochko E.O.

1990 Redkiy pogrebalnyi kompleks katakombnoy kultury na Srednom Dnestre. In: O.G. Shaposhnikova, V.V. Otroschenko, S.Z. Pustovalov, G.N. Toschev, G.I. Shapovalov (Eds) Problemy izucheniya katakombnoy kulturno-istoricheskoy obschnosti, 28-30. Zaporozhe.

Kośko A. (Ed.)

2015 Podolia as a cultural contact area in the 4th/3rd-2nd millennium BC. Baltic-Pontic Studies 20.

Kośko A., Klochko V.I., Olszewski A.

2012 Ritualniy obiekt naselennia prichornomorskoyi kulturnoyi spilnoty doby rannoyi bronzy na r. San. Arkheologiya 2(2012): 67-75.

Kośko A., Klochko V.I., Olszewski A., Włodarczak P., Goslar T.

2018 Święte 11, feature 1149: sequence of funerary rites practiced by Corded Ware people and Early Bronze Northern Pontic cultures. Baltic-Pontic Studies 23: 69-92.

Kruk J., Milisauskas S., Włodarczak P.

2018 The real time. Radiocarbon dates and Bayesian analysis of the Neolithic settlement at Bronocice, fourth millennium BC. Kraków. 
Krywalcewicz M.

2007 Prorwa 1. Cmentarzysko z połowy III - początku II tysiaclecia przed Chr. Na górnym Naddnieprzu. Archaeologia Bimaris - Monografie 2. Poznań.

Kubera M., Zawiślak P.

2016 Grób kultury ceramiki sznurowej na stanowisku 10 w Lagiewnikach, pow. lubelski. In: P. Jarosz, J. Libera, P. Włodarczak (Ed.), Schyłek neolitu na Wyżynie Lubelskiej, 349-358. Kraków.

Kurzyk K.

2011 Pozostałości kurhanu starosznurowego w Żyglądzie, gm. Papowo Biskupie, stanowisko 26 (ziemia chełmińska). In: H. Kowalewska-Marszałek, P. Włodarczak (Eds) Kurhany i obrzadek pogrzebowy w IV-II tysiacleciu p.n.e., 459-466. Kraków, Warszawa.

Ligoda J., Podgórska-Czopek J.

2011 Katalog. In: S. Czopek (Ed.) Autostradq w przesztość. Katalog wystawy, 133-295. Rzeszów.

Machnik J.

1966 Studia nad kulturq ceramiki sznurowej w Małopolsce. Wrocław-Warszawa-Kraków.

Machnik J.

1979 Krąg kulturowy ceramiki sznurowej. In: W. Hensel, T. Wiślański (Eds) Prahistoria ziem polskich. Vol. II. Neolit. Wrocław-Warszawa-Kraków-Gdańsk, 337-411.

1992 Neue Daten zur Problematik der Schnurkeramikkultur in Südostpolen. In: M. Buchvaldek, C. Strahm (Eds) Die kontinentaleuropäischen Gruppen der kultur mit Schnurkeramik. Schnurkeramik - Symposium 1990. Praehistorica 19, 265-274. Praha.

1994 Dwa nurty rozwoju kultury ceramiki sznurowej w Małopolsce. Sprawozdania Archeologiczne 46: 7-12.

1997 Zwei Entwicklungswege der Schnurkeramikkultur in den Flussgebieten der oberen Weischel, Bug und Dnestr. In: P. Siemen (Ed.) Early Corded Ware Culture, The A-Horizont - fiction or fact? International symposium in Jutland 2nd-7th May 1994. Arkæologiske Rapporter 2, 147-156. Esbjerg.

1998 Uwagi o najstarszym osadnictwie pasterskiej ludności kultury ceramiki sznurowej (III tysiąclecie przed Chr.) w strefie karpackiej. In: J. Gancarski (Ed.) Dzieje Podkarpacia. Tom 2, 99-120. Krosno.

1999 Radiocarbon chronology of the Corded Ware Culture on Grzęda Sokalska. A Middle Dnieper traits perspective. Baltic-Pontic Studies: 221-250. 
Machnik J., Bagińska J., Koman W.

2001 Nowa, synkretyczna grupa kultury ceramiki sznurowej w Polsce środkowo-wschodniej. In: B. Ginter, B. Drobniewicz, B. Kazior, M. Nowak, M. Połtowicz (Eds) Księga jubileuszowa dedykowana Profesorowi Januszowi K. Kozłowskiemu w czterdziestolecie pracy naukowej w Uniwersytecie Jagiellońskim, 391-400. Kraków.

2009 Neolityczne kurhany na Grzędzie Sokalskiej w świetle badan archeologicznych w latach 1988-2006. Z aneksami Jerzego Libery i Lucjana Gaz$d y$. Kraków.

Machnik J., Jarosz P., Mazurek M.

2018 Groby kultury ceramiki sznurowej w Mirocinie, pow. Przeworsk. In: P. Jarosz, J. Machnik (Eds) Nekropolie ludności kultury ceramiki sznurowej z III tysiąclecia przed Chr. w Mirocinie na Wysoczyźnie Kańczuckiej. Rzeszów.

Machnik J., Pilch A.

1997 Zaskakujące odkrycie zabytków kultury środkowodnieprzańskiej w Młodowie-Zakąciu koło Lubaczowa w woj. przemyskim. Sprawozdania Archeologiczne 49: 143-170.

Machnik J., Sosnowska E.

1996 Starożytna mogiła z początku III tysiq̨clecia przed Chrystusem, ludności kultury ceramiki sznurowej w Średniej, gm. Krzywcza. Rocznik Przemyski 32(3): 3-28.

1998 Kurhan ludności kultury ceramiki sznurowej z przełomu III i II tysiaclecia przed Chrystusem w Woli Wegierskiej, gm. Roźwienica, woj. przemyskie. Rocznik Przemyski 34(3): 3-20.

Machnik J., Ścibior J.

1991 Die Chronologie der Schnurkeramikkultur (Schk) in Südostpolen. In: C. Strahm (Ed.) Die kontinentaleuropäischen Gruppen der Kultur mit Schnurkeramik. Praha-Štiřin 1-6.10. 1990. Die Chronologie der regionalen Gruppen, Zusammenfassungen, 45-54. Freiburg i. Br.

Moskal del Hoyo M., Krąpiec M., Niezabitowska-Wiśniewska B.

2017 The chronology of site 3 in Ulów (Tomaszów Lubelski district, east Poland): the relevance of anthracological analysis for radiocarbon dating at a multicultural site. Radiocarbon 59(5): 1399-1413.

Müller J.

1999 Zur absoluten Chronologie der mitteldeutschen Schnurkeramik. Erste Ergebnisse eines Datierungsprojektes. Archäologisches Nachrichtenblatt 4(1): 77-88.

2000 Radiokarbonchronologie - Keramiktechnologie - Osteologie - Anthropo- 
logie - Raumanalysen. Beiträge zum Neolithikum und zur Frühbronzezeit im Mittelelbe-Saale-Gebiet. Bericht der Römisch-Germanischen Komission 80 (1999): 31-211.

Niezabitowska-Wiśniewska B., Wiśniewski T.

2011 Kurhanu kultury ceramiki sznurowej na stanowisku 3 w Ulowie, pow. tomaszowski. In: H. Kowalewska-Marszałek, P. Włodarczak (Eds) Kurhany i obrzadek pogrzebowy w IV-II tysiącleciu p.n.e., 329-369. Kraków-Warszawa.

Nikolova A.V.

2012 Absolutna khronologiya yamnoi kultury pivnichnogo Nadcharnomoria v svitli dendrodat. Arkheologiya 4(2012): 14-31.

Nikolova A.V., Kaiser E.

2009 Die absolute Chronologie der Jamnaja Kultur im nordlichen Schwarzmeergebiet auf der Grundlage erster dendrochronologischer Daten. Eurasia Antiqua 15: 209-240.

Olszewski, Włodarczak

2018 Święte 11: cemetery of the Corded Ware culture. Baltic-Pontic Studies 23: $7-68$.

Otroshchenko V.V.

2013 The Catacomb cultures phenomenon. Baltic-Pontic Studies 18: 21-38.

Pospieszny Ł., Sobkowiak-Tabaka I., Price D., Frei K.M., Hildebrandt-Radke I., Kowalewska-Marszałek H., Krenz-Niedbała M., Osypińska M., Stróżyk M., Winiarska-Kabacińska M.

2015 Remains of a late Neolithic barrow at Kruszyn. A glimpse of ritual and everyday life in early Corded Ware societies of the Polish Lowland. Praehistorische Zeitschrift 90(1-2): 185-213.

Rassamakin Y.Y., Nikolova A.V.

2008 Carpathian Imports and Imitations in Context of the Eneolithic and Early Bronze Age of the Black Sea Steppe Area. In: P.F. Biehl, Y.Y. Rassamakin (Eds) Import and Imitation in Archaeology, 51-87. Langenweisbach.

Reimer P.J., Bard E., Bayliss A., Beck W.J., Blackwell P.G., Bronk-Ramsey C., Buck C.E., Cheng H., Edwards R.L., Friedrich N., Grootes P.M., Guilderson T. P., Hafidason H., Hajdas I., Hatte C., Heaton T.J., Hoffmann D.L., Hogg A.G., Hughen K.A., Kaiser K.F., Kromer B., Manning S.V., Niu M., Reimer R.W., Richards D.A., Scott E.M., Southon J.R., Staff R.A., Turney S.M., Van der Plicht J.

2013 IntCal13 and Marine13 radiocarbon age calibration curves 0-50,000 years cal BP. Radiocarbon 55: 1869-1887. 
Rodak T.

2011 Chronologia bezwzględna grobu kultury ceramiki sznurowej ze stanowiska 4 w Lelowicach, pow. proszowicki, woj. małopolskie. In: H. Kowalewska-Marszałek, P. Włodarczak (Eds) Kurhany i obrzadek pogrzebowy w IV-II tysiącleciu p.n.e. Kraków, 231-234. Warszawa.

Rybicka M., Pelisiak A.

2013 Stanowisko 158 w Jarosławiu, woj. podkarpackie. Część I. Kultura malicka i kultura mierzanowicka. Via Archaeologica Ressoviensia 3. Rzeszów.

Rybicka M., Głowacz M., Król D.

2017 Datowania radiowęglowe wielokulturowego cmentarzyska ze Skołoszowa, stanowisko 7, pow. jarosławski, woj. podkarpackie. In: M. Rybicka (Ed.) Wielokulturowe cmentarzysko w Skołoszowie, stanowisko 7 pow. jarosławski w kontekście osadnictwa z neolitu $i$ wczesnej epoki brazu we wschodniej części Podgórza Rzeszowskiego, 113-142. Rzeszów.

Stöckli W. E.

2009 Chronologie und Regionalität des jüngeren Neolithikums (4300-2400v. Chr.) im Schweizer Mitteland, in Süddeutschland und in Ostfrankreich. Antiqua 45. Basel.

Struve K. H.

1955 Die Einzelgrabkultur in Schleswig-Holstein und ihre kontinentalen Beziehungen. Offa-Bücher 11. Neumünster.

Szczepanek A., Belka Z., Jarosz P., Włodarczak P., Pospieszny Ł., Dopieralska J., Frei K.M., Rauba-Bukowska A., Werens K., Górski J., Hozer M., Mazurek M.

2018 Understanding Final Neolithic communities in south-eastern Poland: New insights on diet and mobility from isotopic data. PloS One 13: e0207748.

Ślusarska K.

2006 Funeral rites of the Catacomb Communty: 2800-1900 BC. Ritual, thanatology and geographical origins. Baltic-Pontic Studies 13.

Telegin D.Y., Pustovalov S.Z., Kovalyukh N.N.

2003 Relative and absolute chronology of Yamnaya and Catacomb monuments. The issue of coexistence. Baltic-Pontic Studies 12: 132-184.

Toschev G.N.

2013 In the west of the Catacomb area. Baltic-Pontic Studies 18: 72-85.

Tunia K., Włodarczak P.

2002 Radiocarbon Results for the Corded Ware Culture from Southern Poland. Przegląd Archeologiczny 50: 45-55. 
Wilk S.

2013 A Złota culture cemetery at Książnice site 2, świętokrzyskie province. Cmentarzysko kultury złockiej na stan. 2 w Książnicach, woj. świętokrzyskie. Sprawozdania Archeologiczne 65: 311-338/338-362.

Włodarczak P.

1998 Chronologia absolutna grupy krakowsko-sandomierskiej kultury ceramiki sznurowej na podstawie danych z cmentarzyska w Żernikach Górnych. Sprawozdania Archeologiczne 50: 31-54.

2001 The absolute chronology of the Corded Ware culture in the south-eastern Poland. In: Czebreszuk J., Müller J. (Eds) The absolute chronology in central Europe during the 3rd millenium BC, 103-129. Poznań-Bamberg-Rahden/Westf.

2006 Kultura ceramiki sznurowej na Wyżynie Małopolskiej. Kraków.

2007 Problem chronologii radiowęglowej kultury ceramiki sznurowej w świetle dendrochronologicznych datowań późnoneolitycznych osad palafitowych ze Szwajcarii. Archeologia Polski 52: 35-80.

2008 Kultura złocka i problem genezy kultury ceramiki sznurowej w Małopolsce. In: J. Bednarczyk, J. Czebreszuk, P. Makarowicz, M. Szmyt (Eds) Na pograniczu światów. Studia z pradziejów międzymorza bałtycko-pontyjskiego ofiarowane Profesorowi Aleksandrowi Kośko w 60. rocznice urodzin, 555-576. Poznań.

2009 Radiocarbon and dendrochronological dates of the Corded Ware culture. Radiocarbon 51/2: 737-749.

2013 Projekt badań chronologii absolutnej eneolitu i początków epoki brązu w Małopolsce. In: I. Cheben, M. Sojak (Eds) Otázky neolitu a eneolitu našich krajín - 2010, 373-387. Nitra.

2014 The traits of Early-Bronze Pontic cultures in the development of old upland Corded Ware (Małopolska groups) and Złota culture communities. Baltic-Pontic Studies 19: 7-52.

2016 Chronologia absolutna cmentarzysk późno- i schyłkowoneolitycznych na Wyżynie Lubelskiej. In: P. Jarosz, J. Libera, P. Włodarczak (Eds) Schyłek neolitu na Wyżynie Lubelskiej, 537-548. Kraków.

2017 Toward the Bronze Age in south-eastern Poland (2300-2000 BC). In: P. Włodarczak (Ed.) The Past Societies. 2. 5500-2000 BC. Polish lands from the first evidence of human presence to the early Middle Ages, 377-397. Warszawa.

Włodarczak P., Boroń T., Kurzawska A., Osypińska M., Szczepanek A., Winiarska-Kabacińska M.

2016 Grób kultury ceramiki sznurowej ze stanowiska 10 w Wilczycach, pow. sandomierski. Przegląd Archeologiczny 64: 29-57. 